\title{
Article \\ Quality Assessment of Groundwater Resources in the City of Al-Marj, Libya
}

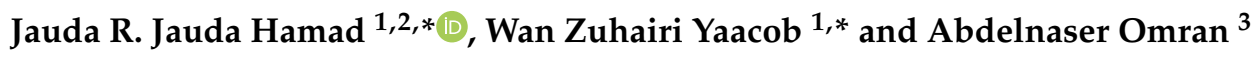 \\ 1 Geology Programme, School of Environmental and Natural Resource Sciences, Faculty of Science and \\ Technology, Universiti Kebangsaan Malaysia, Bangi 43600, Selangor, Malaysia \\ 2 Marine Science Department, Faculty of Natural Resource and Environmental Science, \\ Omar Al-Mukhtar University, Al Bayda' 00218-84, Libya \\ 3 Faculty of Engineering Sciences, Bright Star University, El Breqa 00218-64, Libya; \\ naser_elamroni@yahoo.co.uk \\ * Correspondence: Joda.moonal3@gmail.com (J.R.J.H.); yaacobzw@ukm.edu.my (W.Z.Y.); \\ Tel.: +60-129208785 (J.R.J.H.); +60-193396975 (W.Z.Y.)
}

Citation: Hamad, J.R.J.; Yaacob, W.Z.; Omran, A. Quality Assessment of Groundwater Resources in the City of Al-Marj, Libya. Processes 2021, 9, 154. https://doi.org/10.3390/pr9010154

Received: 27 November 2020 Accepted: 21 December 2020 Published: 15 January 2021

Publisher's Note: MDPI stays neutral with regard to jurisdictional clai$\mathrm{ms}$ in published maps and institutional affiliations.

Copyright: (C) 2021 by the authors. Licensee MDPI, Basel, Switzerland. This article is an open access article distributed under the terms and conditions of the Creative Commons Attribution (CC BY) license (https:// creativecommons.org/licenses/by/ $4.0 /)$.
Abstract: This study aimed to assess and compare the quality of groundwater in the city of Al-Marj in Libya with the international standard guidelines for drinking water recommended by the World Health Organisation. An evaluation of the groundwater wells in the study area was conducted. Standard techniques, such as Minitab (v. 16) and ArcGIS (v.10.2), were used for the analytics of the physicochemical and biological parameters of the groundwater samples. An assessment of the calculation of groundwater quality was conducted on the basis of temperature, $\mathrm{pH}$, turbidity, electrical conductivity, total dissolved solids, chloride, sulphate, bicarbonate, total hardness, calcium, potassium, magnesium, ammonia, ammoniacal nitrogen, nitrate, sodium, copper, iron, dissolved oxygen, biochemical oxygen demand, chemical oxygen demand, total suspended solids, Escherichia coli and total coliform bacteria. Results indicated that most groundwater wells in the study area display a higher concentration of several parameters compared with the permissible limits of drinking water; thus, the water in these wells is chemically and biologically unsafe for drinking purposes. On the basis of the above results, routine water quality monitoring should be performed and additional water filtration plants should be installed by the local government to obtain safe drinking water.

Keywords: groundwater; physicochemical and biological parameters; water quality index; Al-Marj city

\section{Introduction}

Water is a fundamental element in the life of every creature. It is primarily obtained from two sources, surface water and groundwater [1], and roughly one-third of the world's population utilises groundwater for drinking purposes [2]. Groundwater is a valuable natural water reservoir that can be regarded as a safe and accessible water source for residential use [3]. Groundwater has been used as a preferred source of drinking water in arid and semiarid areas [4]. Water sources in Libya come from four sources, with groundwater providing almost $95 \%$ of the country's needs; surface water, including rainwater and dam constructions, as well as desalinated seawater and wastewater recycling [5]. Groundwater is the principal source of drinking and irrigation water in the African continent [4,5]. The major livelihood of the residents of the city of Al-Marj is agriculture, and they heavily rely on groundwater for drinking, domestic, livestock, and agricultural purposes [6]. Therefore, with the increasing demand for groundwater, its quality and sustainability have become the focus of public health and food manufacturing industries worldwide. Water contamination is a major issue that occurs in the groundwater of developed and developing countries [7]. Thus, the estimation of groundwater quality is indispensable to define hygienic and appropriate groundwater sources. The human population in numerous areas of the world are facing critical issues of water supply and contamination, 
African countries confront difficulties in obtaining safe drinking water and satisfactory sanitation [8]. Groundwater contamination is particularly acute in arid or semiarid countries where water supply is scarce [1]. Groundwater quality in Libya is a critical issue that threatens human health due to the high concentration of some chemical and physical parameters [9]. The appropriate grade of water and its permission for drinking and other regional uses rely on its physicochemical and microbiological characteristics [10]. Statistically, $80 \%$ of illnesses in developing nations are directly connected with the insalubrious status of drinking water. In addition, the contamination of groundwater is related to unsanitary and polluted drinking water, which causes illnesses, including cholera, diarrhoea, dysentery, and hepatitis. Each year, more than 842,000 people worldwide die from diarrhoea [11]. Therefore, the main aim of this work is to assess groundwater quality by testing 11 groundwater wells in the study area on the basis of physicochemical and bacteriological parameters.

\section{Materials and Methodology}

\subsection{Description of the Study Area}

The study was conducted in the city of Al-Marj in Libya. The city is located in the north-eastern part of Libya and lies on the bank of the Mediterranean Sea. It covers an area of approximately $10,000 \mathrm{~km}^{2}$. The regulatory seat of Al-Marj was known as Barca. Al-Marj is arranged on the Cyrenaica level at the western edge of Jebel Akhdar and had an estimated population of 85,315 at the beginning 2012 with coordinates $32^{\circ} 29^{\prime} 12^{\prime \prime} \mathrm{N}$ $20^{\circ} 50^{\prime} 02^{\prime \prime} \mathrm{E}$ [12]. The study area is considered one of the most valuable regions in Libya because of its location relative to the Green Mountain, as well as its agricultural activities, including irrigated and non-irrigated cultivation and animal wealth as well as economic activities. The precise locations of the sampling points of the groundwater wells were determined in the field using GARMIN GPSMAP 67CSx (Handheld, Lenexa, MD, USA).

The study area is influenced by the Mediterranean climate, which is characterised by hot, dry summers and mild, rainy winters. The study area has a dry climate, such as that of a semidesert, showing minimal rainfall and high evaporation rates and a clear appearance of aridity, which prevails over the entire area. The climatic characteristics were obtained from the Al-Marj meteorological station, the nearest to the study area. The average annual rainfall is $380 \mathrm{~mm}^{-1}$ year $^{-1}$. December, January and February have the highest rates of precipitation and lower temperatures during the year, whereas the average yearly temperature is $18.8^{\circ} \mathrm{C}$. The highest relative humidity appears in January and February, with an average of $71 \%$, and it decreases in May and June, with an average of $50 \%$; the highest wind speed appears in December, January and February, reaching up to $10 \mathrm{~km} / \mathrm{h}$, and the average annual wind speed is $8.6 \mathrm{~km} / \mathrm{h}$ [13]. An assessment of 11 groundwater wells in the study area was conducted to determine the degree of water quality, as shown in Figure 1.

\subsection{Description of the Groundwater Wells}

Groundwater wells are the primary water source in Libya, including the city of AlMarj; these wells are used for different purposes, such as drinking and irrigation. Eleven groundwater wells were surveyed in terms of criticality, coordinates, elevation, depth, age, and locality; these wells are situated in the farms around the city with the purpose to determine the water quality at the study area, as shown in Table 1.

\subsection{Sample Collection and Analysis}

Firstly, data collection mining was performed to obtain the pertinent information needed for this research. The samples for primary information were all gathered from the groundwater wells in the study area. The sampling of data collection and laboratory extraction of primary data started on 1 June 2017 and was completed on 25 August 2017. In accordance with the procedures indicated in [14], water samples from 11 groundwa- 
ter wells were collected. A total of 33 water samples were collected from the studied groundwater wells.

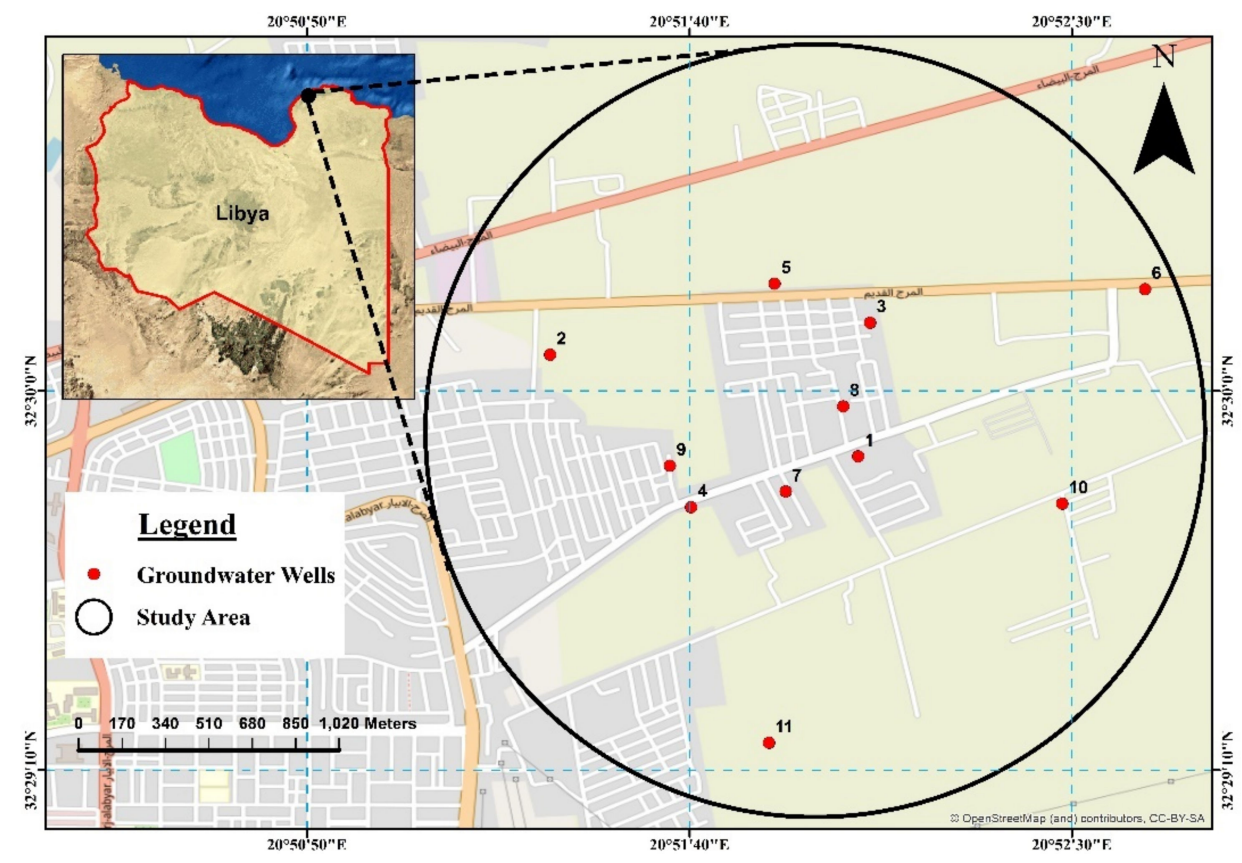

Figure 1. The groundwater wells in the study area.

Table 1. Description of groundwater wells.

\begin{tabular}{|c|c|c|c|c|c|c|}
\hline \multirow{2}{*}{ No. } & \multirow{2}{*}{ Wells Name } & \multicolumn{2}{|c|}{ Coordinates } & \multirow{2}{*}{ Elevation (m) } & \multirow{2}{*}{ Depth of wells (m) } & \multirow{2}{*}{ Wells Age (Year) } \\
\hline & & Latitude & Longitude & & & \\
\hline 1 & Salah Amtaual & 32.497556 & 20.864528 & 284 & 280 & 1978 \\
\hline 2 & Salam Edaab & 32.501167 & 20.853667 & 300 & 472 & 1979 \\
\hline 3 & Al Marthi & 32.502306 & 20.864944 & 292 & 200 & 2001 \\
\hline 4 & Saad Mokhtar & 32.495750 & 20.858639 & 297 & 228 & 1965 \\
\hline 5 & Al Sahly & 32.503694 & 20.861583 & 296 & 200 & 1978 \\
\hline 6 & Ali Ibrahim & 32.5035 & 20.874639 & 288 & 262 & 2010 \\
\hline 7 & Agdora Al Abidi & 32.496306 & 20.861972 & 295 & 301 & 2002 \\
\hline 8 & Mohamad Abd Raba & 32.499333 & 20.864 & 296 & 250 & 1999 \\
\hline 9 & Sediq Al Rashed & 32.497222 & 20.857889 & 314 & 280 & 1978 \\
\hline 10 & Idris Moftah & 32.436833 & 20.882028 & 356 & 365 & 1998 \\
\hline 11 & Abo Shuisha & 32.428333 & 20.871694 & 363 & 300 & 2008 \\
\hline
\end{tabular}

The coordinates in the decimal degrees system.

Water samples were pumped out of boreholes at a fast rate to cool the metal pipe and thus eliminate the influence of water temperature on the pipe. The pumping was sustained for at least $5 \mathrm{~min}$. Generally, water samples were collected from groundwater wells using $500 \mathrm{~mL}$ glass bottles. The glass bottles were cleaned with warm water and soap and then rinsed with double distilled water and a few drops of $5 \% \mathrm{HNO}_{3}$ were added to avoid microbial activities. Afterwards, the bottle was rinsed with some of the water and then filled, leaving no air space; then, the bottles were immediately covered. Separate samples were obtained for chemical and biological examination with the appropriate procedures for sampling and protection of the samples. To ensure that the evaluations were accurate and reproducible, after every 10 samples, blank, standard and pre-analysed samples were examined. The standard processes by [15] were used to analysed all of the samples. 
Water samples were transported to the laboratory in a cool box with ice and analysed within $6 \mathrm{~h}$. Samples meant for metal analysis were stored in a refrigerator at $4{ }^{\circ} \mathrm{C}$. Then, water samples were carried and analysed carefully in the laboratory of Abutaraba desalination plant, which is located nearly $20 \mathrm{~km}$ north of the city of Al-Marj.

The physical parameters of the water samples were determined in accordance with the standard method in $[15,16]$. The measured physical parameters are as follows:

Temperature was measured using an HI 98517 (Hanna Instruments, Smithfield, RI, USA) and was calibrated and set to $25^{\circ} \mathrm{C}$; whereas $\mathrm{pH}$ was measured using an HI 9024-C (Hanna Instruments, Smithfield, RI, USA), and the calibration of the $\mathrm{pH}$ meter used the standard buffer solutions of $\mathrm{pH}$ 4, 7, and 10. A LaMotte turbidimeter (Model: 2020 we/wi, LaMotte Company, Chestertown, MD, USA) was calibrated by using formazin standards to measure the turbidity of the water samples. Electrical conductivity (EC), dissolved oxygen (DO), and total dissolved solids (TDS) were measured using a YSI multiparameter water quality meter (Model: 3100C, Xylem, Westchester County, NY, USA). Measurements were made using the standard methods recommended by [15] and Canada CCME [16]. The mensuration was repeated thrice for each parameter reading, and the average was taken. These six physical parameters were chosen on the basis of their relevance to the general water quality constituents as pollution indicator parameters.

Thirteen chemical parameters were included to examine the quality of water. The parameters are as follows: Chloride was determined by Mercuric Thiocyanate Method (HACH method 8113); detection range 0.1 to $25.0 \mathrm{mg} / \mathrm{L} \mathrm{Cl}^{-}$; wavelength $455 \mathrm{~nm}$ reported in [16]. The Turbidimetric Method was used to measure the $\mathrm{SO}_{4}{ }^{2-}$. The $\mathrm{NO}_{3}{ }^{-}$was measured via an Ultraviolet Spectrophotometer Screening Method by (DR 2800, Hach). The MB3000 Fourier Transform Infrared Spectroscopy (Perkin-Elmer, Waltham, MA, USA) was used to measure the $\mathrm{HCO}_{3}{ }^{-}$at 2345 wavenumbers. A flame photometer (model CL-360, Elico, Baden, Switzerland) was utilized to measure the $\mathrm{Na}$ and $\mathrm{K}$. Ca and $\mathrm{Mg}$ were analysed by used the complexometric titration EDTA (ethylenediaminetetraaceticacid) Titration Method as described in [17]. Total hardness was counted by the total of Ca and $\mathrm{Mg}$ altogether. The salicylate method of Ammonia Salicylate Powder Pillow $(10,205)$ 0 to $10 \mathrm{mg} / \mathrm{L} \mathrm{NH}_{3}-\mathrm{N}$ was used to measure $\mathrm{NH}_{3}$ and $\mathrm{NH}_{3}-\mathrm{N}$ by using the Hach DR 2800 spectrophotometer. Biochemical oxygen demand was determined by the 5-day Biochemical Oxygen Demand Dilution Method prescribed by Hach Method 10,230. COD was evaluated using a Hach DRB200 reactor and a Hach DR6000 spectrophotometer (Reactor Digestion Method) with the potassium acid phthalate; determination of COD was detected in limitation of 0.7 to $40.0 \mathrm{mg} / \mathrm{L}$. The photometric method (Hach method 8006; detection range: 5-750 mg/L; wavelength: $810 \mathrm{~nm}$ ) was used to determine the total suspended solids (TSS). The chemical analysis of the groundwater samples was conducted in accordance with the standard method recommended by Hach [18]. Copper and Iron were examined via ICP-MS (Inductively Coupled Plasma Mass Spectrometry) and Strong Acid ( $\left.\mathrm{HNO}_{3} / \mathrm{HCL}\right)$ digestion Method 200.2. E. coli and total coliforms (TC) in each sample were determined using the Membrane Filtration Method 8074.

For the statistical analysis, Minitab software version 16 was used to obtain the mean, standard deviation and $p$-value; one-way analysis of variance (ANOVA) was performed to determine the significant difference between each value. Inverse distance weighted interpolation was used to present the quality of water on the basis of each parameter. By using ArcGIS 10.1 software, each physicochemical and biological parameter was interpolated with Inverse Distance Weighting (IDW), and maps were created.

\section{Results and Discussions}

The physicochemical and biological parameters measured from groundwater wells were precisely analysed and compared with the regulatory standards set by the World Health Organisation. 


\subsection{Temperature}

The temperature of the groundwater wells varied between 20.8 and 23.2, as presented in Table 2. The lowest temperature was found in the Al Marthi groundwater well (20.8 \pm 2.2$)$, whereas the highest temperature was recorded in the Salam Edaab groundwater well $(23.3 \pm 1.2)$. This finding is similar to that of a previous study by Mostafa et al. [19], who revealed that the variation in groundwater temperature may be due to dissimilarities in the collection time, which fluctuates from one period to another. Another study by Parmar [20] examined the groundwater quality in five villages of Chalisgaon in India and confirmed that the temperature of the groundwater wells varied within approximately $30^{\circ} \mathrm{C}$ from August 2009 to April 2011, and the mean temperature was $27.40{ }^{\circ} \mathrm{C}$ in all seasons for both years. No statistically significant differences were found in the temperature of the groundwater wells $(p$-value $=0.965)$.

Table 2. Descriptive statistics and $p$-value of Temperature $\left({ }^{\circ} \mathrm{C}\right)$.

\begin{tabular}{cccccccccccc}
\hline Groundwater Wells & $\mathbf{1}$ & $\mathbf{2}$ & $\mathbf{3}$ & $\mathbf{4}$ & $\mathbf{5}$ & $\mathbf{6}$ & $\mathbf{7}$ & $\mathbf{8}$ & $\mathbf{9}$ & $\mathbf{1 0}$ & $\mathbf{1 1}$ \\
\hline Mean & 21.8 & 23.2 & 20.8 & 21.2 & 22.1 & 21.8 & 22.3 & 21.6 & 21 & 22.2 & 22.3 \\
Std Dev & 2.9 & 1.2 & 2.2 & 2.6 & 1.2 & 1.9 & 2.1 & 1.5 & 2.5 & 2 & 2.4 \\
$p$-Value & 0.965 & & & & & & & & & & \\
WHO's guideline & - & & & & & & & & & & \\
\hline
\end{tabular}

The spatial distribution of temperature within the groundwater wells is shown in Figure 2. The groundwater temperature is usually equivalent to the mean air surface temperature, and it typically stays within a small area all year round. The fluctuation in the groundwater's temperature was linked to the well's temperature tendency, lithology profile and geological environment, as well as the depth of the aquifers [21]. Similar results in terms of groundwater temperature were found by Chacha et al. [22], who conducted research in Arusha in northern Tanzania and confirmed that the groundwater temperature ranged from $19.4{ }^{\circ} \mathrm{C}$ to $24.5^{\circ} \mathrm{C}$. The temperature in Figure 2 shows that the measured temperature often decreases with depth.

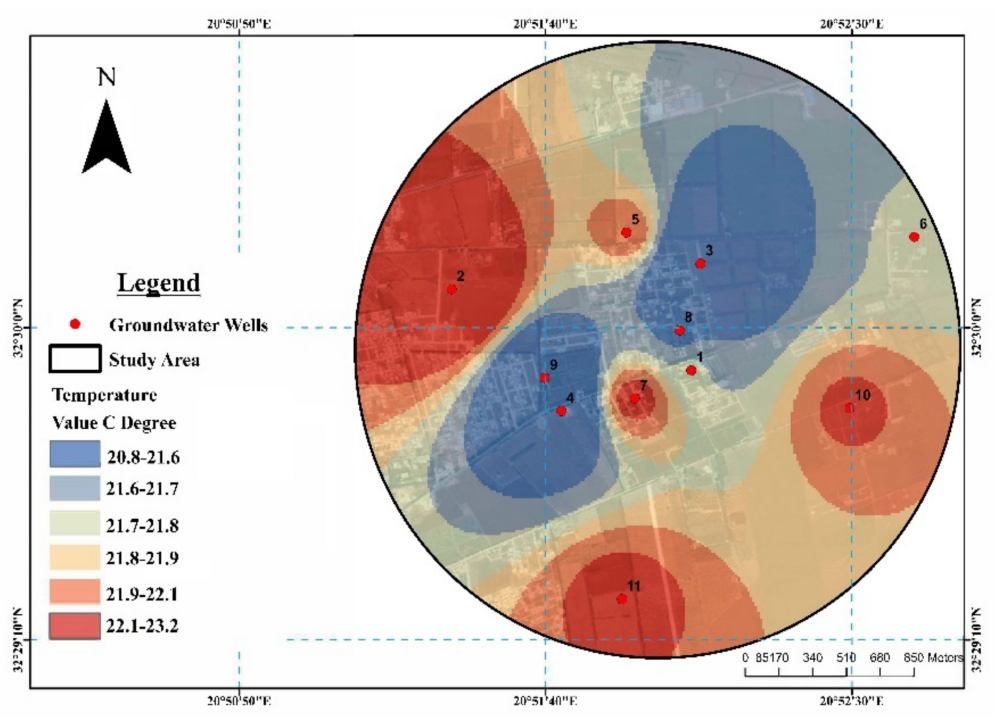

Figure 2. Spatial distribution map of Temperature.

\section{2. $p H$}

The water samples from the groundwater wells had a total $\mathrm{pH}$ between 6.6 and 7.3, as shown in Table 3. The lowest $\mathrm{pH}$ was found in the Sediq Al Rashed groundwater well $(6.6 \pm 1.2)$, whereas the highest value was recorded in the Abo Shuisha groundwater well $(7.3 \pm 1)$. A similar finding was observed by Suk-Ueng et al. [23], who stated that the 
$\mathrm{pH}$ range varied between 6.96 and 8.5 and indicated the alkaline nature of the groundwater. No significant differences were found amongst the $\mathrm{pH}$ of the groundwater wells ( $p$-value $=0.099)$. Therefore, the $\mathrm{pH}$ of the groundwater wells is acceptable on the basis of the WHO's recommended limit for drinking water [24].

Table 3. Descriptive statistics and $p$-value of $\mathrm{pH}$.

\begin{tabular}{cccccccccccc}
\hline Groundwater Wells & $\mathbf{1}$ & $\mathbf{2}$ & $\mathbf{3}$ & $\mathbf{4}$ & $\mathbf{5}$ & $\mathbf{6}$ & $\mathbf{7}$ & $\mathbf{8}$ & $\mathbf{9}$ & $\mathbf{1 0}$ & $\mathbf{1 1}$ \\
\hline Mean & 7.1 & 7.2 & 7 & 6.9 & 7.1 & 7.2 & 7.2 & 7.1 & 6.6 & 7 & 7.3 \\
Std Dev & 0.95 & 0.96 & 0.55 & 0.85 & 0.7 & 1.1 & 1.2 & 0.95 & 1.2 & 0.8 & 1 \\
$p$-Value & 0.99 & & & & & & & & & & \\
WHO's guideline & $6.5-8.5$ & & & & & & & & & & \\
\hline
\end{tabular}

The distribution of $\mathrm{pH}$ within the groundwater wells ranged between 6.5 and $>7.3$, as shown in Figure 3. A similar finding was discovered by Brhane [25], who studied the groundwater quality in Adiabat, Ethiopia and reported that the $\mathrm{pH}$ distribution was within 6.5-8.5. In [26], the $\mathrm{pH}$ of the groundwater wells in the city of Konya in Turkey was reported to be distributed within 7.0-8.6.

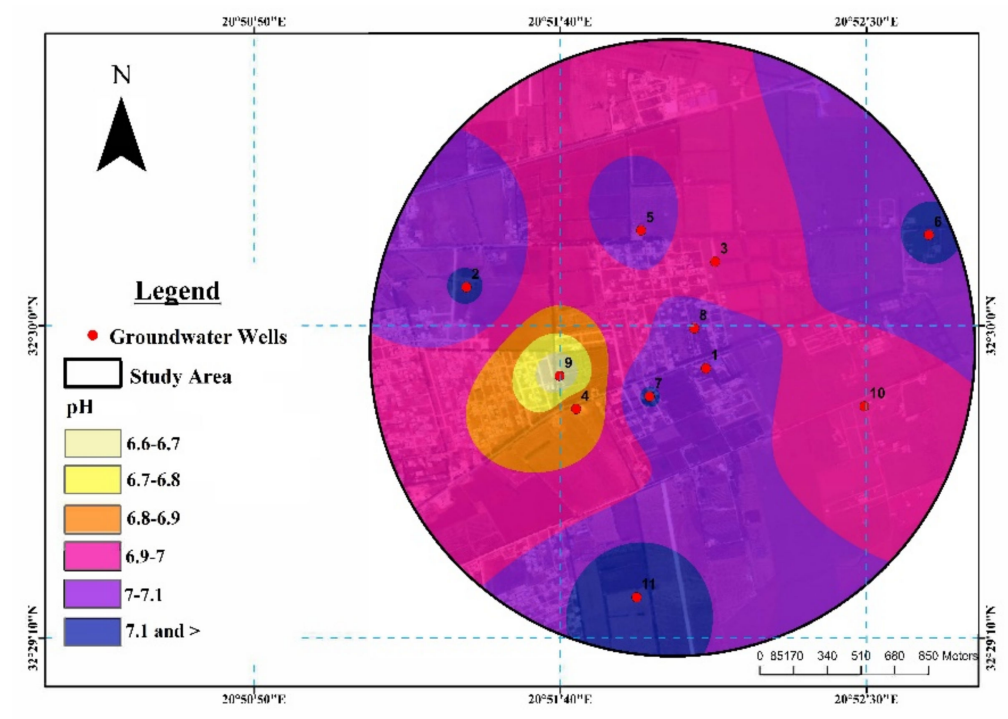

Figure 3. Spatial distribution map of $\mathrm{pH}$.

\subsection{Turbidity}

The turbidity of the groundwater wells in the study area ranged from 0.2 to 1.2 nephelometric turbidity units (NTU), as shown in Table 4. The lowest level of turbidity (i.e., $0.2 \mathrm{NTU}$ ) was found in two groundwater wells (Salah Amtaual and Idris Moftah), and the highest quantity was recorded in the Al Marthi groundwater well (1.2 $\pm 0.8 \mathrm{NTU})$. The high value of turbidity was due to the discharge of the residential area's sewage that reached the groundwater well and the soil erosion caused by natural phenomena and human activities near the study area. Akinbile and Yusoff [27] conducted an analogous study of groundwater quality in the city of Akure in Nigeria and confirmed that the turbidity ranged between 1.6 and $6.6 \mathrm{NTU}$; some of the studied groundwater wells were above the recommended value for drinking water (i.e., $<5$ NTU). The turbidity quantum within the groundwater wells showed no statistically significant differences $(p$-value $=0.076$ ). Therefore, the turbidity level of the groundwater wells was within the limit of the guidelines for drinking water. In the current research, the turbidity value did not cross the limit of the WHO guidelines for drinking water [24]. 
Table 4. Descriptive statistics and $p$-value of Turbidity (NTU).

\begin{tabular}{cccccccccccc}
\hline Groundwater Wells & $\mathbf{1}$ & $\mathbf{2}$ & $\mathbf{3}$ & $\mathbf{4}$ & $\mathbf{5}$ & $\mathbf{6}$ & $\mathbf{7}$ & $\mathbf{8}$ & $\mathbf{9}$ & $\mathbf{1 0}$ & $\mathbf{1 1}$ \\
\hline Mean & 0.2 & 0.3 & 1.2 & 0.4 & 0.5 & 0.6 & 0.7 & 0.8 & 0.6 & 0.2 & 0.3 \\
Std Dev & 0.08 & 0.1 & 0.8 & 0.2 & 0.2 & 0.4 & 0.2 & 0.4 & 0.09 & 0.2 & 0.2 \\
$p$-Value & 0.076 & & & & & & & & & & \\
WHO's guideline & 5 & & & & & & & & & & \\
\hline
\end{tabular}

The concentration and distribution of turbidity within groundwater wells were distributed from 0.2 to $<0.7 \mathrm{NTU}$, as shown in Figure 4. Turbidity refers to the cloudiness of water caused by suspended solids (e.g., clay and sediments), various chemical sources (e.g., manganese and iron), biological substances (e.g., agricultural debris), and microorganisms [28]. Thus, groundwater wells located near an inoperative wastewater treatment station exhibit high turbidity. Turbidity is assumed to be mainly for aesthetics in water sources, and evidence has been found to prove that managing turbidity is an effective defence against contaminants in drinking water [29].

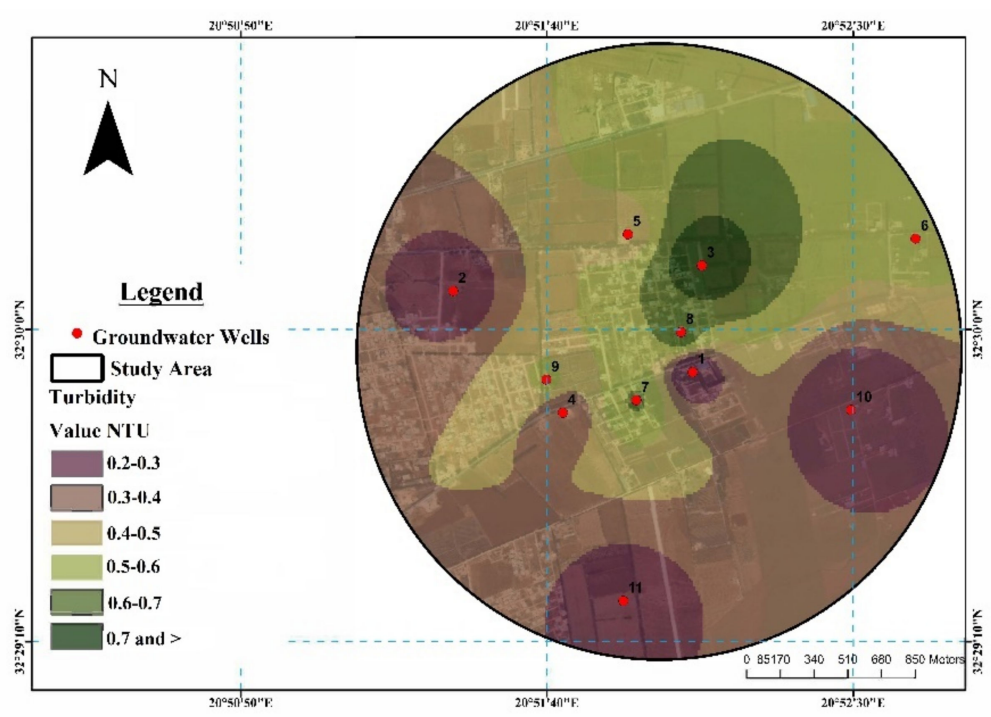

Figure 4. Spatial distribution map of Turbidity.

\subsection{Electrical Conductivity}

The EC of the tested groundwater wells varied between 826 and $1711 \mu \mathrm{S} / \mathrm{cm}$, as shown in Table 5. The Abo Shuisha groundwater well had a low EC value ( $826 \pm 11.5)$, and that of the Al Marthi groundwater well had a high EC value (1711 \pm 10$)$. The obtained values of EC of the studied groundwater wells were above the permissible limit of drinking water (i.e., $300 \mu \mathrm{S} / \mathrm{cm}$ ); these results indicate the strong mineralisation of the groundwater wells. This phenomenon might be due to the discharge of sewage water from the residential area towards the groundwater wells in the city. Qaseem and Al-Barwary [30] evaluated the groundwater quality in Iraq and showed that the high EC value was due to the high level of dissolved chemical ions in the groundwater wells; the flow of water through calcite rocks resulted in high TDS. Significant differences were found amongst the EC of the studied groundwater wells $(p$-value $=0.00$ ).

Table 5. Descriptive statistics and $p$-value of Electrical Conductivity ( $\mu \mathrm{s} / \mathrm{cm})$.

\begin{tabular}{cccccccccccc}
\hline Groundwater Wells & $\mathbf{1}$ & $\mathbf{2}$ & $\mathbf{3}$ & $\mathbf{4}$ & $\mathbf{5}$ & $\mathbf{6}$ & $\mathbf{7}$ & $\mathbf{8}$ & $\mathbf{9}$ & $\mathbf{1 0}$ & $\mathbf{1 1}$ \\
\hline Mean & 1479 & 1513 & 1711 & 1514 & 1564 & 1497 & 1648 & 1522 & 1530 & 905 & 826 \\
Std Dev & 16.5 & 4.6 & 10 & 16 & 3.6 & 15.5 & 8.5 & 9 & 95.6 & 13.1 & 11.5 \\
$p$-Value & 0.00 & & & & & & & & & & \\
WHO's guidelines & 300 & & & & & & & & & & \\
\hline
\end{tabular}


The spatial variation of EC in the groundwater wells is shown in Figure 5. The distribution of EC in the measured groundwater wells may be due to the effectiveness of the depth amongst the groundwater wells. However, a broad range of high EC values was found in the groundwater wells due to the sewage discharge in the area. Alfaifi et al. [28] assessed the groundwater quality in the city of Najran in the southern part of Saudi and found that the distribution range of EC was from $1791 \mathrm{~S} / \mathrm{cm}$ to $2622 \mathrm{~S} / \mathrm{cm}$.

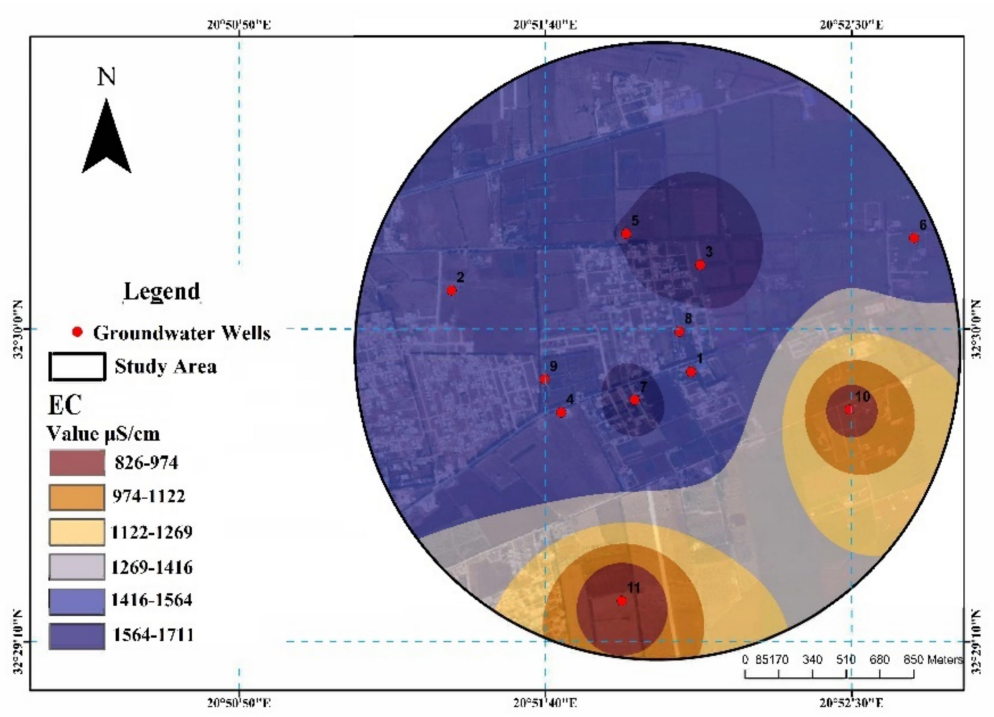

Figure 5. Spatial distribution map of Electrical Conductivity.

\subsection{Total Dissolved Solids}

The TDS value varied between 412 and $854 \mathrm{mg} / \mathrm{L}$ in the tested groundwater wells, as listed in Table 6. The lowest TDS was recorded in the Abo Shuisha groundwater well (412 \pm 4.6$)$, whereas the highest level was observed in the Al Marthi groundwater well $(854 \pm 4.5)$. The palatability of water with a TDS below $600 \mathrm{mg} / \mathrm{L}$ is generally considered to be satisfactory; drinking water becomes unpalatable in higher TDS levels (i.e., $>1000 \mathrm{mg} / \mathrm{L}$ ) [15]. Similar findings were reported by Mahmood et al. [31], who conducted a study in the city of Kirkuk in Iraq and showed that TDS ranged from $401 \mathrm{mg} / \mathrm{L}$ to $759 \mathrm{mg} / \mathrm{L}$. Except for that of the Abo Shuisha groundwater well, the TDS value of the studied groundwater wells exceeded the allowable limit for drinking water (i.e., $500 \mathrm{mg} / \mathrm{L}$ ) recommended by the WHO [24]. Results of the one-way ANOVA showed significant differences amongst the TDS of the examined groundwater wells $(p$-value $=0.00)$.

Table 6. Descriptive statistics and $p$-value of Total Dissolved Solids (mg/L).

\begin{tabular}{cccccccccccc}
\hline Groundwater Wells & $\mathbf{1}$ & $\mathbf{2}$ & $\mathbf{3}$ & $\mathbf{4}$ & $\mathbf{5}$ & $\mathbf{6}$ & $\mathbf{7}$ & $\mathbf{8}$ & $\mathbf{9}$ & $\mathbf{1 0}$ & $\mathbf{1 1}$ \\
\hline Mean & 739 & 757 & 854 & 756 & 782 & 748 & 824 & 761 & 765 & 452 & 412 \\
Std Dev & 12 & 12.3 & 4.5 & 13.5 & 3.6 & 11 & 8.2 & 8.5 & 6 & 18 & 4.6 \\
$p$-Value & 0.00 & & & & & & & & & & \\
WHO's guidelines & 500 & & & & & & & & & & \\
\hline
\end{tabular}

Figure 6 illustrates the spatial distribution of TDS on the groundwater wells. Accordingly, TDS may enter the groundwater by recharging water that has been polluted by human use via wastewater or returning agricultural drainage to groundwater wells. The quality of groundwater for drinking can be expressed in terms of TDS concentration [32]. Groundwater with a low TDS value of $300 \mathrm{mg} / \mathrm{L}$ can be considered suitable for drinking [24]. A high value of TDS indicates the presence of numerous cations and anions in the water [33]. 


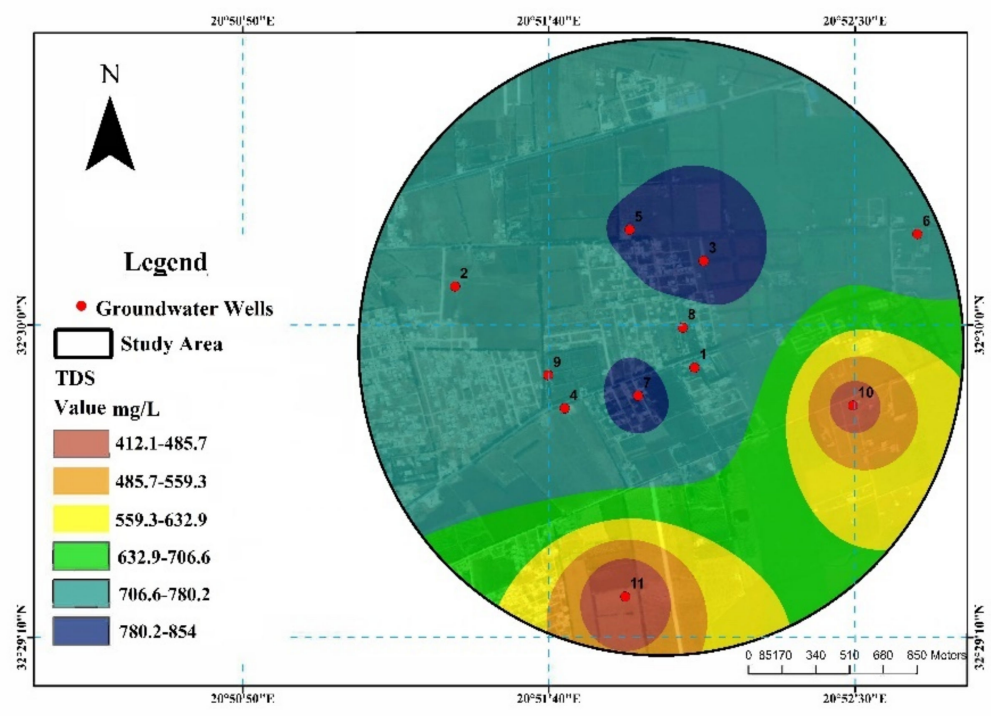

Figure 6. Spatial distribution map of Total Dissolved Solids.

\subsection{Chloride}

The chloride concentration within the groundwater wells ranged between $134.3 \mathrm{mg} / \mathrm{L}$ and $353.1 \mathrm{mg} / \mathrm{L}$, as shown in Table 7. The lowest value was found in the Abo Shuisha groundwater well $(134.3 \pm 5.7)$, and the highest level was recognised in the Al Marthi groundwater well $(353.1 \pm 6.5)$. Only two groundwater wells had a chloride concentration lower than the WHO-recommended allowable limit for drinking water (i.e., $250 \mathrm{mg} / \mathrm{L}$ ) [24]. The exponential rise in $\mathrm{Cl}^{-}$concentration may be linked to the geographical location of the groundwater wells, i.e., near a deactivated wastewater treatment station. High chloride concentration in groundwater originates from natural sources, sewage and industrial effluents, and urban runoff containing de-icing salt and saline intrusion. Wei et al. [34] examined the quality of groundwater in Taiwan and observed that the concentration of $\mathrm{Cl}^{-}$ranged from $550 \mathrm{mg} / \mathrm{L}$ to $6190 \mathrm{mg} / \mathrm{L}$. Significant differences were found amongst the chloride concentration of the evaluated groundwater wells $(p$-value $=0.00)$.

Table 7. Descriptive statistics and $p$-value of Chloride (mg/L).

\begin{tabular}{cccccccccccc}
\hline Groundwater Wells & $\mathbf{1}$ & $\mathbf{2}$ & $\mathbf{3}$ & $\mathbf{4}$ & $\mathbf{5}$ & $\mathbf{6}$ & $\mathbf{7}$ & $\mathbf{8}$ & $\mathbf{9}$ & $\mathbf{1 0}$ & $\mathbf{1 1}$ \\
\hline Mean & 288 & 283.4 & 353.1 & 285 & 281.3 & 284.4 & 319 & 282 & 282.6 & 147.6 & 134.3 \\
Std Dev & 11 & 3 & 6.5 & 14.7 & 7 & 9 & 6.2 & 4.6 & 7 & 10.1 & 5.7 \\
$p$-Value & 0.00 & & & & & & & & & & \\
WHO's guideline & 250 & & & & & & & & & & \\
\hline
\end{tabular}

Figure 7 elucidates the spatial distribution of $\mathrm{Cl}^{-}$on the groundwater wells in the study area. The distribution of $\mathrm{Cl}^{-}$in the studied groundwater wells was analysed. High concentrations of $\mathrm{Cl}^{-}$were found in most of the groundwater wells, except for two wells; the nine groundwater wells exceeded the allowable limit of chloride in groundwater [24]. Based on the spatial distribution of $\mathrm{Cl}^{-}$, high concentrations were found in most groundwater wells; the high chloride level could be due to industrial and domestic wastes, leaching in dry climates from the upper soil layers and natural geophysical activities in the region [35]. 


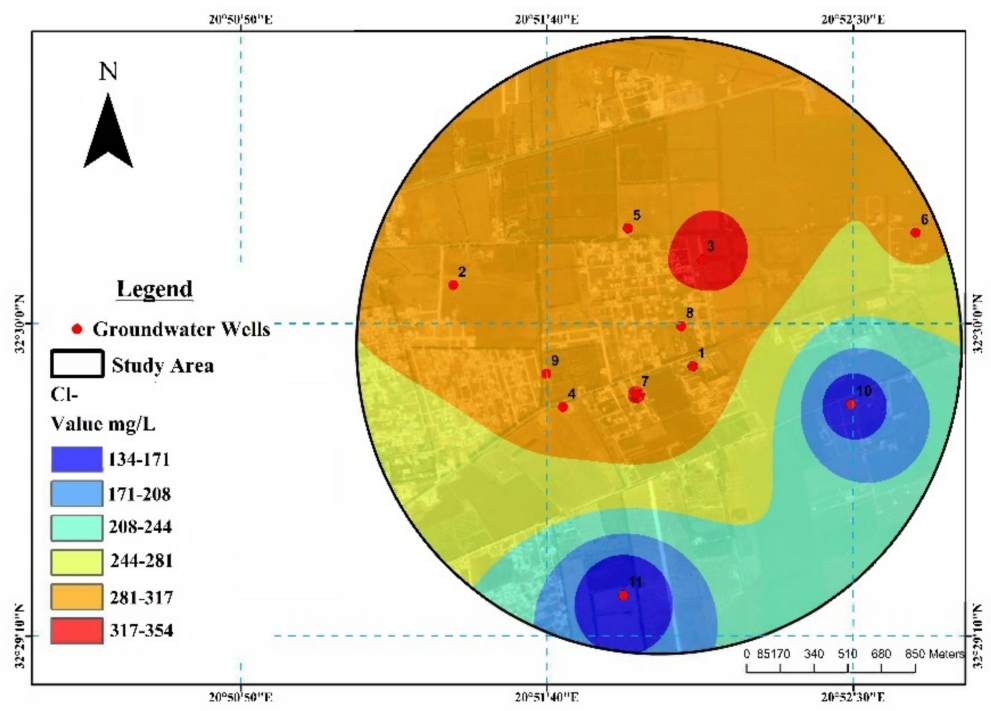

Figure 7. Spatial distribution map of Chloride.

\subsection{Sulphate}

The concentration of $\mathrm{SO}_{4}{ }^{2-}$ in the measured groundwater wells was within $20-69 \mathrm{mg} / \mathrm{L}$, as shown in Table 8. The lowest level of $\mathrm{SO}_{4}{ }^{2-}$ concentration was observed in the Abo Shuisha groundwater well (20 \pm 4$)$, whereas the highest concentration was found in the Ali Ibrahim groundwater well $(69 \pm 8.2)$. The concentration of $\mathrm{SO}_{4}{ }^{2-}$ in the groundwater wells was below the prescribed level of $250 \mathrm{mg} / \mathrm{L}$. A high concentration of $\mathrm{SO}_{4}{ }^{2-}$ is expected in groundwater wells near disrupted wastewater treatment stations adjacent to the same area of groundwater wells or intensively irrigated areas. It can also come from the degradation of organic materials; dissolved wastes, such as building waste or ash; synthetic detergents; and inert wastes, such as dredging. $\mathrm{SO}_{4}{ }^{2-}$ typically occurs naturally in numerous minerals and is predominantly used in the chemical industry [15]. Therefore, elevated $\mathrm{SO}_{4}{ }^{2-}$ concentrations may be derived from seawater or generated by pyrite oxidation [36]. A groundwater quality assessment conducted by Nas and Berktay [26] in the city of Konya in Turkey revealed that the mean concentration of $\mathrm{SO}_{4}{ }^{2-}$ was $50 \mathrm{mg} / \mathrm{L}$. The one-way ANOVA findings showed significant variations in sulphate concentration amongst the groundwater wells $(p$-value $=0.00)$.

Table 8. Descriptive statistics and $p$-value of Sulfate (mg/L).

\begin{tabular}{cccccccccccc}
\hline Groundwater Wells & $\mathbf{1}$ & $\mathbf{2}$ & $\mathbf{3}$ & $\mathbf{4}$ & $\mathbf{5}$ & $\mathbf{6}$ & $\mathbf{7}$ & $\mathbf{8}$ & $\mathbf{9}$ & $\mathbf{1 0}$ & $\mathbf{1 1}$ \\
\hline Mean & 38 & 30 & 51 & 30 & 40.7 & 69 & 47 & 34 & 31.7 & 21.3 & 20 \\
Std Dev & 5.5 & 6 & 7.5 & 5.5 & 9.6 & 8.2 & 9.6 & 6.2 & 2.5 & 3.5 & 4 \\
$p$-Value & 0.00 & & & & & & & & & & \\
WHO's guideline & 250 & & & & & & & & & & \\
\hline
\end{tabular}

Figure 8 shows the spatial variation of $\mathrm{SO}_{4}{ }^{2-}$ concentration in the investigated groundwater wells. The high level of sulphate in the groundwater wells could be due to the discharge of different polluting substances in the area. Lorite-Herrera and Jiménez-Espinosa [37] experimentally analysed the groundwater quality in Jae' $n$, Spain and found that the other sources of sulphate in groundwater may be agricultural practices; they also reported that groundwater is mainly saturated or slightly supersaturated for calcite in the aquifer. 


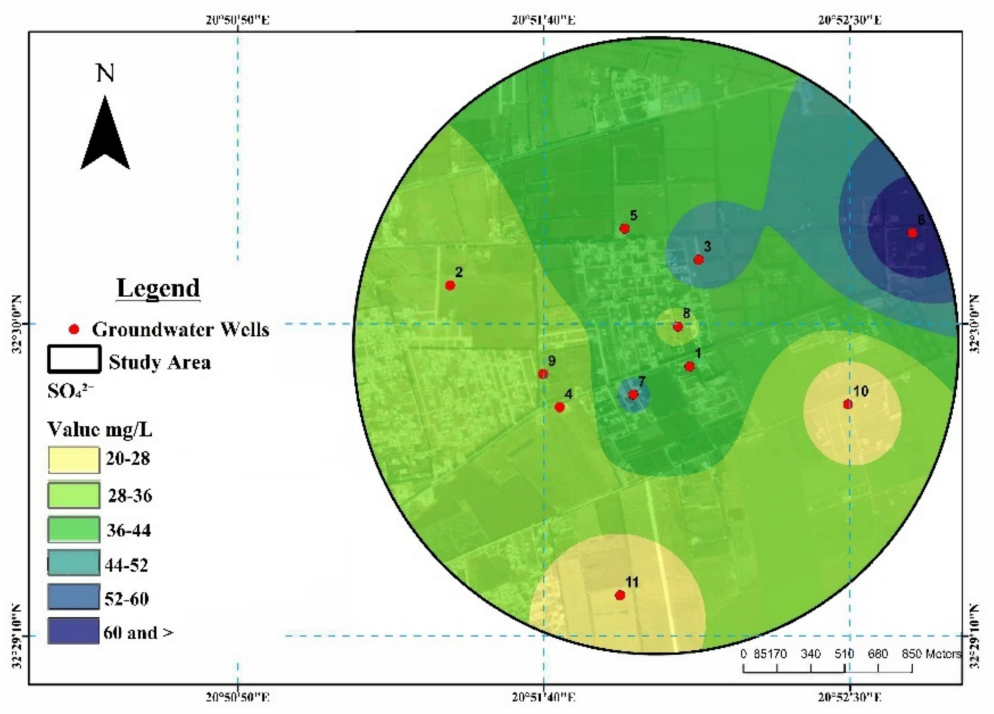

Figure 8. Spatial distribution map of Sulfate.

\subsection{Bicarbonate}

The bicarbonate concentration in the groundwater wells ranged from $101 \mathrm{mg} / \mathrm{L}$ to $161 \mathrm{mg} / \mathrm{L}$, as shown in Table 9. The Idris Moftah groundwater well had a low level of $\mathrm{HCO}_{3}{ }^{-}(101 \pm 4.6)$, whereas the $\mathrm{Al}$ Marthi groundwater well had the highest concentration $(161 \pm 8.5)$. The $\mathrm{HCO}_{3}{ }^{-}$concentration in the groundwater wells was lower than the WHO-recommended limit for drinking water (i.e., <300 mg/L) [24]. In a recent study conducted by Adimalla and Venkatayogi [35], the groundwater quality in India's Medak community was assessed; results revealed that the content of $\mathrm{HCO}_{3}{ }^{-}$in the groundwater wells varied from $18 \mathrm{mg} / \mathrm{L}$ to $527 \mathrm{mg} / \mathrm{L}$, with a mean value of $306.5 \mathrm{mg} / \mathrm{L}$. Biglari et al. [38] examined the groundwater quality parameters in Iran and reported that the average value of $\mathrm{HCO}_{3}{ }^{-}$was $549 \mathrm{mg} / \mathrm{L}$, suggesting that the groundwater wells were contaminated with a high concentration of bicarbonate. Results of the one-way ANOVA indicated significant variations in the bicarbonate concentration of the groundwater wells ( $p$-value $=0.00$ ).

Table 9. Descriptive statistics and $p$-value of Bicarbonate $(\mathrm{mg} / \mathrm{L})$.

\begin{tabular}{cccccccccccc}
\hline Groundwater Wells & $\mathbf{1}$ & $\mathbf{2}$ & $\mathbf{3}$ & $\mathbf{4}$ & $\mathbf{5}$ & $\mathbf{6}$ & $\mathbf{7}$ & $\mathbf{8}$ & $\mathbf{9}$ & $\mathbf{1 0}$ & $\mathbf{1 1}$ \\
\hline Mean & 111 & 125 & 161 & 128 & 110 & 131 & 135 & 151 & 151.3 & 101 & 101.7 \\
Std Dev & 3.6 & 8.7 & 8.5 & 7 & 7.5 & 6.5 & 6 & 8 & 3.8 & 4.6 & 3.5 \\
$p$-Value & 0.00 & & & & & & & & & & \\
WHO's guideline & 300 & & & & & & & & & & \\
\hline
\end{tabular}

The high level of bicarbonate in the groundwater wells may be due to the influence of harmful pollutants emitted from the city to the groundwater wells via sewage flow (See Figure 9). The distribution of $\mathrm{HCO}_{3}{ }^{-}$is supported by a study by Brhane [25], who assessed the quality of groundwater in Tigray, Ethiopia; a considerably high amount of $\mathrm{HCO}_{3}{ }^{-}$was detected in the central region and some points in the northern part of the country due to untreated wastewater that reached the groundwater from old dumpsites and small factories.

\subsection{Total Hardness}

The accumulation of $\mathrm{TH}$ in the groundwater wells ranged from $149 \mathrm{mg} / \mathrm{L}$ to $271 \mathrm{mg} / \mathrm{L}$, as summarised in Table 10. The lowest concentration was found in the Abo Shuisha groundwater well $(149 \pm 3.6)$, and the highest value was recorded in the Ali Ibrahim groundwater well $(271 \pm 8)$. The TH concentration in groundwater was affected by fluctuations in the amount of heavy rain and leachate drainage from farming or agricultural 
fields and by the usage of well water for gardening and farming. On the basis of TH, the water samples can be categorised as soft (greater than 1-70 mg/L), moderately hard (75-150 mg/L), hard (150-300 mg/L), and extremely hard (above $300 \mathrm{mg} / \mathrm{L}$ ) [39]. The analysed groundwater wells were below the acceptable limit of drinking water (i.e., $500 \mathrm{mg} / \mathrm{L}$ ). The water samples were considered suitable for consumption and domestic use and classified as moderately-hard to hard. Significant differences were found amongst the TH of the studied groundwater wells ( $p$-value $=0.00)$.

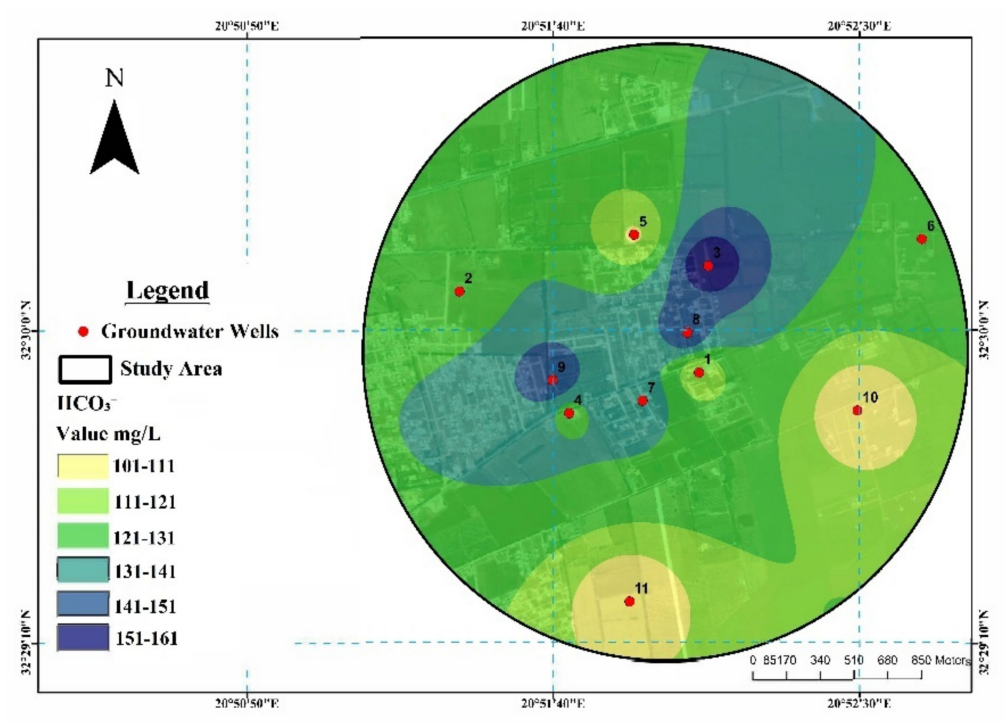

Figure 9. Spatial distribution map of Bicarbonate.

Table 10. Descriptive statistics and $p$-value of Total Hardness (mg/L).

\begin{tabular}{cccccccccccc}
\hline Groundwater Wells & $\mathbf{1}$ & $\mathbf{2}$ & $\mathbf{3}$ & $\mathbf{4}$ & $\mathbf{5}$ & $\mathbf{6}$ & $\mathbf{7}$ & $\mathbf{8}$ & $\mathbf{9}$ & $\mathbf{1 0}$ & $\mathbf{1 1}$ \\
\hline Mean & 228 & 222 & 250.7 & 216 & 271 & 176 & 231 & 219 & 211.7 & 161 & 149 \\
Std Dev & 7 & 6.2 & 2.5 & 3.6 & 3.6 & 8 & 3 & 7.5 & 6.5 & 9.1 & 3.6 \\
$p$-Value & 0.00 & & & & & & & & & & \\
WHO's guideline & 500 & & & & & & & & & & \\
\hline
\end{tabular}

The spatial distribution of TH in the groundwater wells increased from $0 \mathrm{mg} / \mathrm{L}$ to $300 \mathrm{mg} / \mathrm{L}$, as shown in Figure 10. A previous study by James [40] determined the water quality of groundwater wells in the city of Paynesville in Liberia; results showed that the distribution of TH was within $25-425 \mathrm{mg} / \mathrm{L}$. Talat et al. [41] evaluated the quality of groundwater in the city of Mosul city in Iraq and confirmed that the distribution of TH ranged from $460 \mathrm{mg} / \mathrm{L}$ to $2230 \mathrm{mg} / \mathrm{L}$.

\subsection{Calcium}

In comparison with the WHO-recommended limit for drinking water (i.e., $75 \mathrm{mg} / \mathrm{L}$ ) [24], high levels of Ca were recorded in all the groundwater wells, except for the Abo Shuisha groundwater well as shown in Table 11. The abundance of Ca in water is mostly due to its usual presence in Earth's crust. Deshpande et al. [42] examined groundwater quality in the Aurangabad district of India and reported an average Ca value of $112.22-168.33 \mathrm{mg} / \mathrm{L}$. Significant differences were found amongst the Ca concentration of the examined groundwater wells $(p$-value $=0.00)$. 


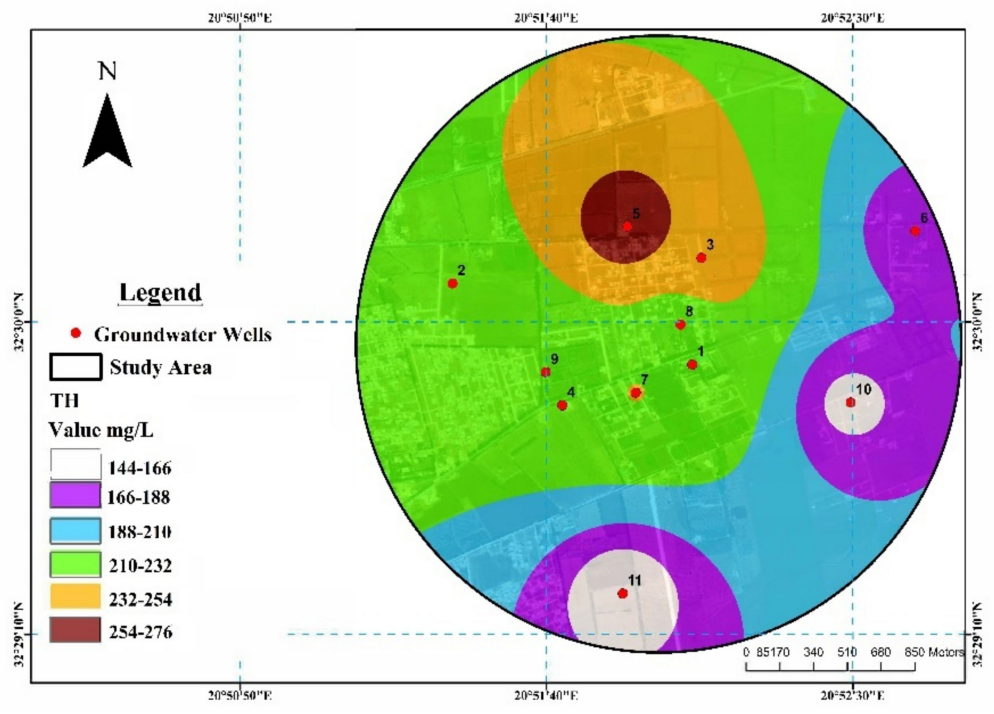

Figure 10. Spatial distribution map of Total Hardness.

Table 11. Descriptive statistics and $p$-value of Calcium (mg/L).

\begin{tabular}{cccccccccccc}
\hline Groundwater Wells & $\mathbf{1}$ & $\mathbf{2}$ & $\mathbf{3}$ & $\mathbf{4}$ & $\mathbf{5}$ & $\mathbf{6}$ & $\mathbf{7}$ & $\mathbf{8}$ & $\mathbf{9}$ & $\mathbf{1 0}$ & $\mathbf{1 1}$ \\
\hline Mean & 124 & 116 & 140 & 127.7 & 167 & 94 & 122 & 110 & 123.7 & 81 & 74 \\
Std Dev & 3.6 & 8.1 & 4 & 6.5 & 5.3 & 4.6 & 3.6 & 6.2 & 3.5 & 2.1 & 6.6 \\
$p$-Value & 0.00 & & & & & & & & & & \\
WHO's guideline & 75 & & & & & & & & & & \\
\hline
\end{tabular}

As shown in the data presented in Figure 11, most of the groundwater wells had a high distribution of $\mathrm{Ca}$, exceeding the WHO-recommended limit for drinking water [24]. The main water chemistry of the groundwater wells may reflect the geology of the area. The total concentration of $\mathrm{Ca}$ is the main factor that increases the hardness of water [43].

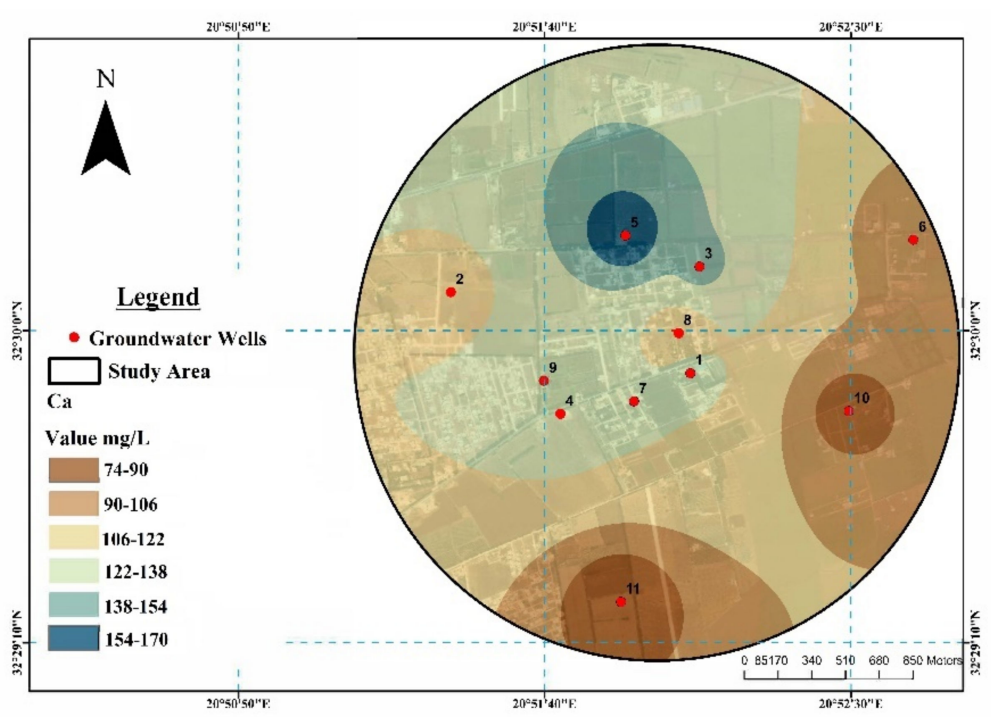

Figure 11. Spatial distribution map of Calcium.

\subsection{Potassium}

The potassium content in the assessed groundwater wells ranged between 2.3 and $12 \mathrm{mg} / \mathrm{L}$, as presented in Table 12. The minimum concentration was found in the Abo Shuisha groundwater well $(2.3 \pm 1.1)$, whereas the maximum concentration was de- 
termined in the Salam Edaab groundwater well $(12 \pm 3)$. The K content in the studied underground wells was within the WHO-recommended limit for drinking water (i.e., $12 \mathrm{mg} / \mathrm{L}$ ) [24]. Potassium may primarily come from rock weathering in addition to solid and liquid wastes [44]. Belkhiri and Narany [45] assessed the quality of subterranean water in Ain Azel, Algeria and discovered that the potassium value ranged from $3.13 \mathrm{mg} / \mathrm{L}$ to $10.03 \mathrm{mg} / \mathrm{L}$. Significant differences were found amongst the potassium level of the studied groundwater wells $(p$-value $=0.00)$.

Table 12. Descriptive statistics and $p$-value of Potassium (mg/L).

\begin{tabular}{cccccccccccc}
\hline Groundwater Wells & $\mathbf{1}$ & $\mathbf{2}$ & $\mathbf{3}$ & $\mathbf{4}$ & $\mathbf{5}$ & $\mathbf{6}$ & $\mathbf{7}$ & $\mathbf{8}$ & $\mathbf{9}$ & $\mathbf{1 0}$ & $\mathbf{1 1}$ \\
\hline Mean & 9.8 & 12 & 9.5 & 11.3 & 6.2 & 6.9 & 8.1 & 10.7 & 11.2 & 2.4 & 2.3 \\
Std Dev & 1.3 & 3 & 1.8 & 2.9 & 0.8 & 0.9 & 1.2 & 1.9 & 1.2 & 0.7 & 1.1 \\
$p$-Value & 0.00 & & & & & & & & & & \\
WHO's guideline & 12 & & & & & & & & & & \\
\hline
\end{tabular}

The results shown in Figure 12 depict that the allocation of potassium in the groundwater wells ranged between 0 and $12 \mathrm{mg} / \mathrm{L}$. The collapsed sewage pipe system in the study area could be the primary source of the increasing amount of pollutants, including potassium, in the groundwater wells. Kringel et al. [46] assessed the aquifer quality of water in the city of Yaounde in Cameroon and revealed that the potassium distribution amongst the groundwater wells varied from $1.1 \mathrm{mg} / \mathrm{L}$ to $26.2 \mathrm{mg} / \mathrm{L}$; the high concentration of potassium in the groundwater could be related to nearby anthropogenic discharges.

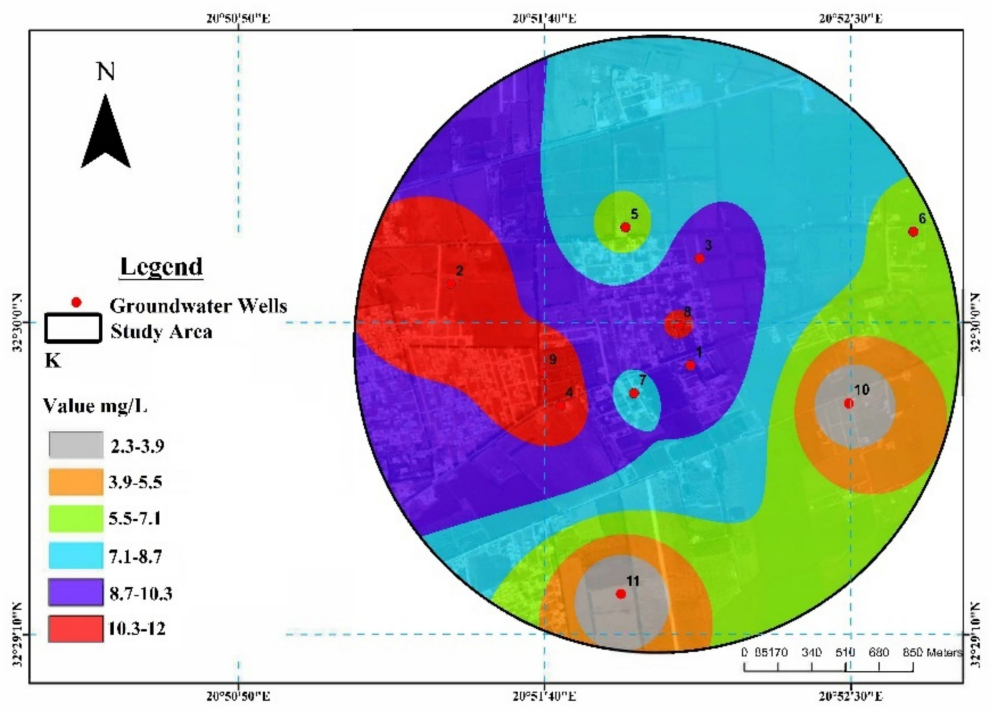

Figure 12. Spatial distribution map of Potassium.

\subsection{Magnesium}

The magnesium concentration in the studied groundwater wells varied from $75 \mathrm{mg} / \mathrm{L}$ to $123.7 \mathrm{mg} / \mathrm{L}$, as shown in Table 13. The lowest content of magnesium was observed in the Abo Shuisha groundwater well $(75 \pm 10)$, whereas the highest level was found in the Sediq Al Rashed groundwater well (123.7 \pm 3.5$)$. The abundance of $\mathrm{Mg}$ in the groundwater wells referred to the dissolution of all solids and rocks but mostly from limestone, dolomite and gypsum, which are found in large quantities in some brines [47,48]. The obtained $\mathrm{Mg}$ concentration in the studied groundwater wells was within the WHO-recommended limit for drinking water (i.e., $150 \mathrm{mg} / \mathrm{L}$ ) [24]. Significant differences were found amongst the $\mathrm{Mg}$ concentration of the groundwater wells $(p$-value $=0.00)$. 
Table 13. Descriptive statistics and $p$-value of Magnesium (mg/L).

\begin{tabular}{cccccccccccc}
\hline Groundwater Wells & $\mathbf{1}$ & $\mathbf{2}$ & $\mathbf{3}$ & $\mathbf{4}$ & $\mathbf{5}$ & $\mathbf{6}$ & $\mathbf{7}$ & $\mathbf{8}$ & $\mathbf{9}$ & $\mathbf{1 0}$ & $\mathbf{1 1}$ \\
\hline Mean & 104 & 106 & 110 & 88.3 & 104 & 82 & 108 & 109 & 123.7 & 80 & 75 \\
Std Dev & 3.6 & 4.4 & 2.6 & 3.1 & 2.6 & 3.6 & 6.6 & 13.1 & 3.5 & 4.6 & 10 \\
$p$-Value & 0.00 & & & & & & & & & & \\
WHO's guideline & 150 & & & & & & & & & & \\
\hline
\end{tabular}

Figure 13 shows the spatial distribution of magnesium in the groundwater wells in the study area. The distribution of $\mathrm{Mg}$ fluctuated in different concentrations on the basis of the geographical location of the groundwater wells. The high distribution of $\mathrm{Mg}$ in the groundwater wells was due to the discharge in the adjacent area of the studied wells. Kouras et al. [49] investigated the quality of underground water in the city of Chalkidiki in Greece and confirmed that the accumulation of $\mathrm{Mg}$ ranged from $21 \mathrm{mg} / \mathrm{L}$ to $278 \mathrm{mg} / \mathrm{L} ; \mathrm{Mg}$ was found to be the dominant cation in groundwater probably due to seawater intrusion.

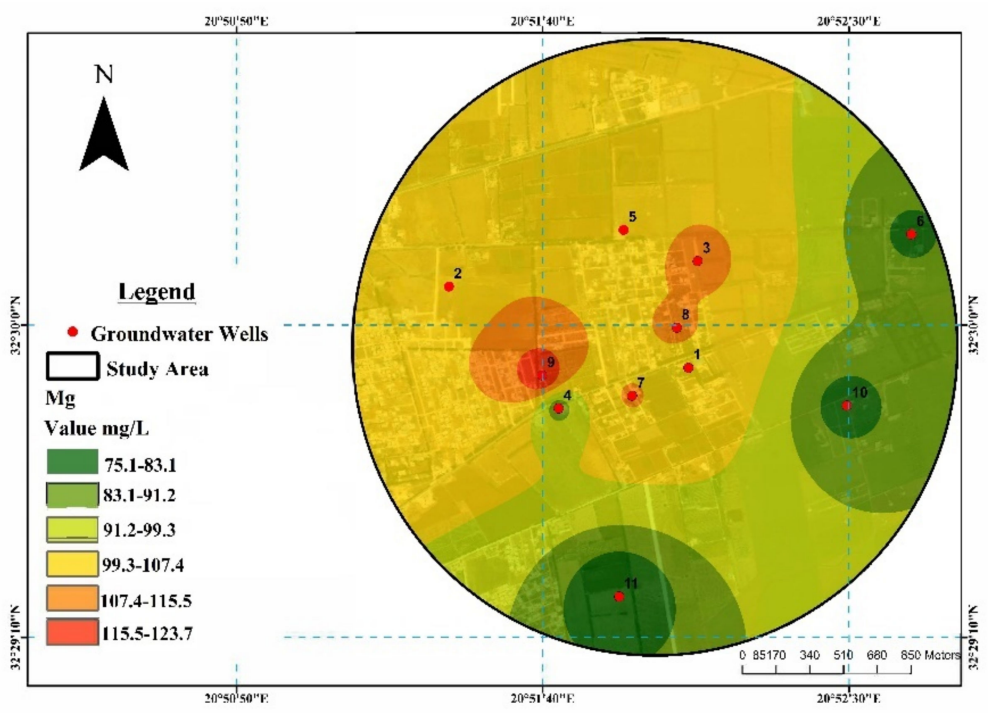

Figure 13. Spatial distribution map of Magnesium.

\subsection{Ammonia}

The ammonia concentration in the groundwater wells was within $0.02-7 \mathrm{mg} / \mathrm{L}$, as shown in Table 14. The lowest value was detected in the Abo Shuisha groundwater well $(0.02 \pm 0.02)$, whereas the highest content was measured in the Saad Mokhtar groundwater well $(7 \pm 1)$. The $\mathrm{NH}_{3}$ abundance in the studied groundwater wells was principally due to agricultural activities and the residential utilisation of $\mathrm{NH}_{3}$ contained in cleaning products that enter the groundwater wells through an improper wastewater network system. Eight groundwater wells were considered polluted with $\mathrm{NH}_{3}$ as they exceeded the WHO-recommended limit for drinking water (i.e., $1.5 \mathrm{mg} / \mathrm{L}$ ) [24]. The presence of $\mathrm{NH}_{3}$ is generally an indicator of domestic wastewater contamination that would be consistent with the strong influence of runoff or other discharges from urban settlements [50]. Significant differences were found amongst the $\mathrm{NH}_{3}$ level of the groundwater wells $(p$-value $=0.00$ ).

Table 14. Descriptive statistics and $p$-value of Ammonia (mg/L).

\begin{tabular}{cccccccccccc}
\hline Groundwater Wells & $\mathbf{1}$ & $\mathbf{2}$ & $\mathbf{3}$ & $\mathbf{4}$ & $\mathbf{5}$ & $\mathbf{6}$ & $\mathbf{7}$ & $\mathbf{8}$ & $\mathbf{9}$ & $\mathbf{1 0}$ & $\mathbf{1 1}$ \\
\hline Mean & 4.4 & 5.1 & 3 & 7 & 0.7 & 1.6 & 2.7 & 4.2 & 4.7 & 0.04 & 0.02 \\
Std Dev & 1.5 & 1.1 & 0.6 & 1 & 0.2 & 0.5 & 0.7 & 0.5 & 0.2 & 0.04 & 0.02 \\
$p$-Value & 0.00 & & & & & & & & & & \\
WHO's guideline & 1.5 & & & & & & & & & & \\
\hline
\end{tabular}


The spatial distribution of ammonia in the groundwater wells fluctuated from $0 \mathrm{mg} / \mathrm{L}$ to $7 \mathrm{mg} / \mathrm{L}$, as depicted in Figure 14. The high distribution of $\mathrm{NH}_{3}$ in the groundwater wells was due to the discharge from the city to the affected wells. Fu et al. [51] found a similar finding in their study of subterranean water quality in China and reported that the $\mathrm{NH}_{3}$ distribution ranged from 0.01 to 7.6. Harms-ringdahl [52] analysed the quality of aquifers of water in the city of Hanoi in Vietnam and identified that the ammonia content in uncontaminated groundwater was lower than $0.2 \mathrm{mg} / \mathrm{L}$ but might be higher in cultivated areas and regions with dense animal production. The presence of $\mathrm{NH}_{3}$ in groundwater is not an immediate health concern, and a high value of this ion indicates water contamination from animal waste or sewage sludge.

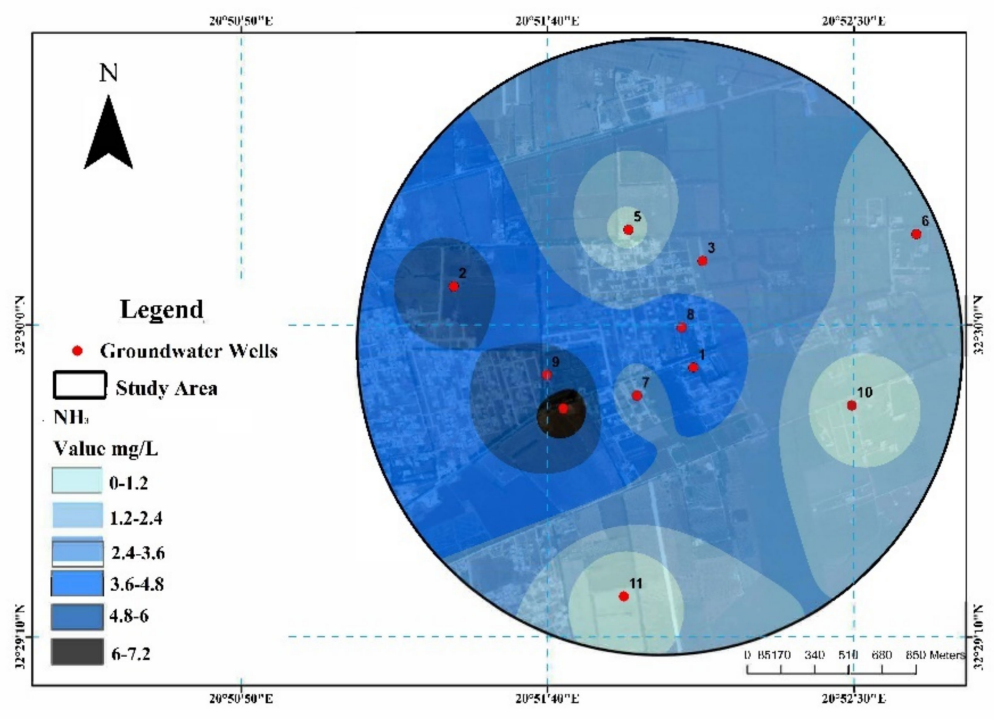

Figure 14. Spatial distribution map of Ammonia.

\subsection{Ammoniacal Nitrogen}

The ammonia nitrogen content varied between 0.01 and $5.8 \mathrm{mg} / \mathrm{L}$ in the studied groundwater wells, as illustrated in Table 15. The highest concentration of $\mathrm{NH}_{3}-\mathrm{N}$ $(5.8 \pm 0.6)$ was found in the Saad Mokhtar groundwater well, whereas the lowest level was discovered in the Abo Shuisha groundwater well $(0.01 \pm 0.02)$. Most of the groundwater wells were considered polluted due to the discharge of city sewage, which run into the wells. Moreover, the wells are located in agricultural areas and might have been affected by fertiliser usage. Jafari and Khayamian [53] evaluated water quality in the city of Isfahan in Iran and reported that the high concentration of $\mathrm{NH}_{3}-\mathrm{N}$ in Zayanderood water could be due to sewage discharged from houses. Shakya et al. [54] tested the quality of groundwater in the city of Kathmandu in Nepal and identified that the average concentration of $\mathrm{NH}_{3}-\mathrm{N}$ was $0.6 \mathrm{mg} / \mathrm{L}$. Significant differences were found amongst the ammonia nitrogen content of the examined groundwater wells $(p$-value $=0.00)$.

Table 15. Descriptive statistics and $p$-value of Ammoniacal Nitrogen (mg/L).

\begin{tabular}{cccccccccccc}
\hline Groundwater Wells & $\mathbf{1}$ & $\mathbf{2}$ & $\mathbf{3}$ & $\mathbf{4}$ & $\mathbf{5}$ & $\mathbf{6}$ & $\mathbf{7}$ & $\mathbf{8}$ & $\mathbf{9}$ & $\mathbf{1 0}$ & $\mathbf{1 1}$ \\
\hline Mean & 3.7 & 4.3 & 2.5 & 5.8 & 0.6 & 1.3 & 2.2 & 3.5 & 3.7 & 0.03 & 0.01 \\
Std Dev & 1.5 & 1.2 & 0.7 & 0.6 & 0.1 & 0.5 & 0.8 & 0.5 & 0.2 & 0.03 & 0.02 \\
$p$-Value & 0.00 & & & & & & & & & & \\
WHO's guideline & 0.1 & & & & & & & & & & \\
\hline
\end{tabular}

The spatial distribution map shows that $\mathrm{NH}_{3}-\mathrm{N}$ contaminated several groundwater wells due to human farm activities and sewage discharge to the groundwater wells (See Figure 15). Wu and Ye [55] conducted a study on groundwater quality in 30 provinces 
in China and stated that the high distribution of $\mathrm{NH}_{3}-\mathrm{N}$ in most groundwater samples could be due to discharge from agricultural, industrial and residential sources. Wakida and Lerner [56] assessed groundwater quality in the city of Nottingham in England and indicated that the primary sources of $\mathrm{NH}_{3}-\mathrm{N}$ were correlated with wastewater disposal and solid waste disposal through the system and leaky sewers.

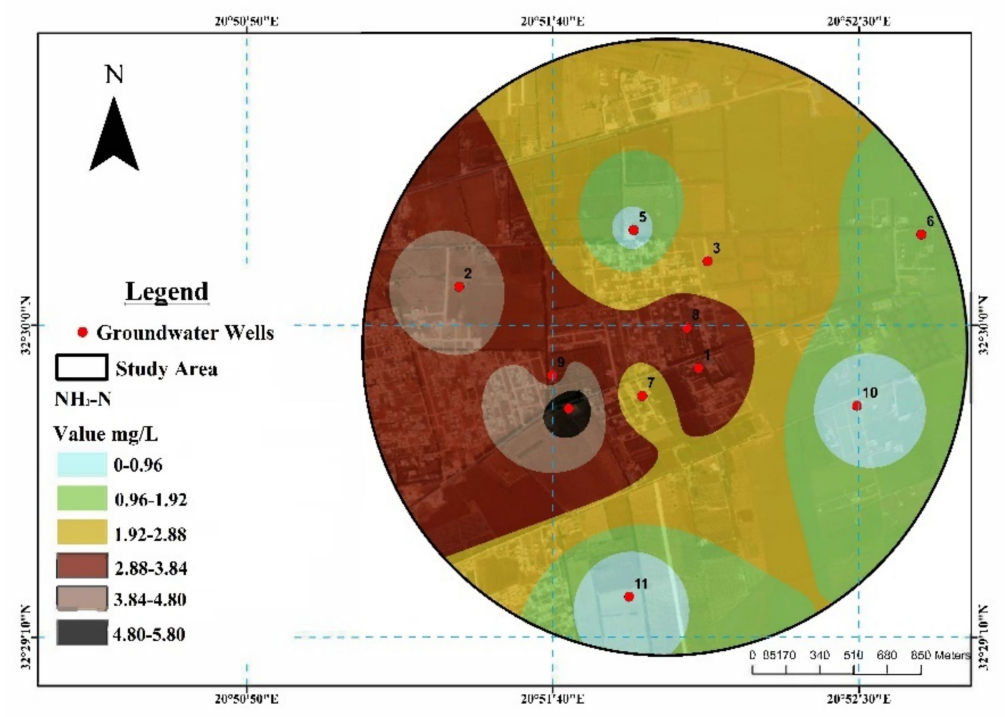

Figure 15. Spatial distribution map of Ammoniacal Nitrogen.

\subsection{Nitrate}

The nitrate concentration in the groundwater wells ranged from $0 \mathrm{mg} / \mathrm{L}$ to $11 \mathrm{mg} / \mathrm{L}$, as shown in Table 16. $\mathrm{NO}_{3}{ }^{-}$was not detected in the Salam Edaab groundwater well. The highest value was found in the Al Sahly well $(11 \pm 1.1)$. The concentration of $\mathrm{NO}_{3}{ }^{-}$ in the examined groundwater wells was lower than the WHO-recommended limit for drinking water (i.e., $50 \mathrm{mg} / \mathrm{L}$ ) [24]. Sources of $\mathrm{NO}_{3}{ }^{-}$pollution are septic tanks, animal and human waste, and commercial fertilisers [57]. Wagh et al. [58] determined the quality of water in the Maharashtra district of India and observed that the concentration of $\mathrm{NO}_{3}{ }^{-}$in the groundwater wells varied between 19.31 and $68.62 \mathrm{mg} / \mathrm{L}$. Significant differences were found amongst the nitrate level of the groundwater wells $(p$-value $=0.00)$.

Table 16. Descriptive statistics and $p$-value of Nitrate (mg/L).

\begin{tabular}{cccccccccccc}
\hline Groundwater Wells & $\mathbf{1}$ & $\mathbf{2}$ & $\mathbf{3}$ & $\mathbf{4}$ & $\mathbf{5}$ & $\mathbf{6}$ & $\mathbf{7}$ & $\mathbf{8}$ & $\mathbf{9}$ & $\mathbf{1 0}$ & $\mathbf{1 1}$ \\
\hline Mean & 2.7 & 0.0 & 4.1 & 0.6 & 11 & 5 & 2.2 & 0.4 & 2.3 & 5.4 & 4.5 \\
Std Dev & 0.5 & 0.0 & 0.8 & 0.1 & 1.1 & 0.8 & 0.2 & 0.3 & 0.9 & 0.4 & 0.3 \\
$p$-Value & 0.00 & & & & & & & & & & \\
WHO's guideline & 50 & & & & & & & & & & \\
\hline
\end{tabular}

Figure 16 shows the spatial distribution of nitrate in the groundwater wells. The level of nitrate was low in some groundwater wells but increased in other wells due to the hydrogeologic features of the well's locations and the cumulative loading of $\mathrm{NO}_{3}{ }^{-}$into the groundwater well reserves via the application of fertilisers. El Hamidi et al. [59] evaluated the spatial distribution of underground wells in a town in Morocco and assessed the quality of water in the Rmel aquifers by detecting nitrate; the result showed that the nitrate level was satisfactory, with a concentration of less than $35 \mathrm{mg} / \mathrm{L}$. Odoma and Ocheri [60] conducted a study in the town of Lokoja in Nigeria and estimated the spatial distribution of nitrate levels in groundwater wells; they observed that the levels in the studied aquifers were below the maximum limit of $50 \mathrm{mg} / \mathrm{L}$. 


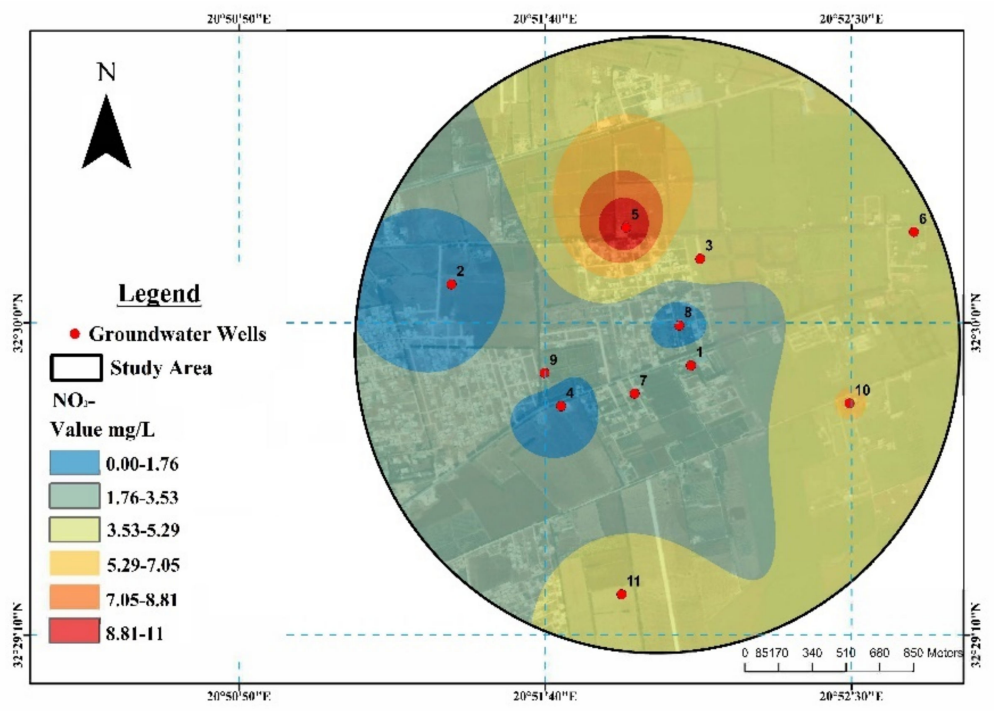

Figure 16. Spatial distribution map of Nitrate.

\subsection{Sodium}

The content of $\mathrm{Na}$ in the groundwater wells ranged between 60.8 and $160 \mathrm{mg} / \mathrm{L}$, as shown in Table 17. The lowest concentration was observed in the Abo Shuisha groundwater well $(60.8 \pm 6.9)$, whereas the highest concentration was found in the Military groundwater well $(160 \pm 8.1)$. A high concentration of $\mathrm{Na}$ in the groundwater wells could indicate sturdy water-aquifer interaction due to the interchange of cations and anthropogenic activities, such as wastewater disposal. Sodium ions naturally occur in water due to some phenomena, such as vaporisation, farming and human activities, and clay weathering [61]. The Na concentration in the groundwater wells was below the WHO's recommended limit for drinking water (i.e., $200 \mathrm{mg} / \mathrm{L}$ ) [24]. Rezaei et al. [62] evaluated the quality of underground water for irrigation and drinking purposes in the village of Dalgan in Iran and proved that the concentration of Na varied between 22.20 and $124.3 \mathrm{mg} / \mathrm{L}$. Significant differences were found amongst the $\mathrm{Na}$ content of the examined groundwater wells $(p$-value $=0.00)$.

Table 17. Descriptive statistics and $p$-value of Sodium (mg/L).

\begin{tabular}{cccccccccccc}
\hline Groundwater Wells & $\mathbf{1}$ & $\mathbf{2}$ & $\mathbf{3}$ & $\mathbf{4}$ & $\mathbf{5}$ & $\mathbf{6}$ & $\mathbf{7}$ & $\mathbf{8}$ & $\mathbf{9}$ & $\mathbf{1 0}$ & $\mathbf{1 1}$ \\
\hline Mean & 153 & 149 & 160 & 63.8 & 136.3 & 150 & 155.3 & 144 & 145.7 & 65.7 & 60.8 \\
Std Dev & 14 & 8.5 & 8.1 & 4.3 & 9.5 & 8.7 & 6 & 8 & 5 & 12 & 6.9 \\
$p$-Value & 0.00 & & & & & & & & & & \\
WHO's guideline & 200 & & & & & & & & & & \\
\hline
\end{tabular}

Figure 17 shows the spatial distribution of sodium in the groundwater wells. The higher distribution of $\mathrm{Na}$ was observed in the middle and eastern portions of the study area. The highest distribution was observed in several groundwater wells due to sewage discharges from the domestic area. Sodium has a large distribution and has a significant proportion in groundwater, indicating that sodium ions can be formed from a wide range of sources [63]. 


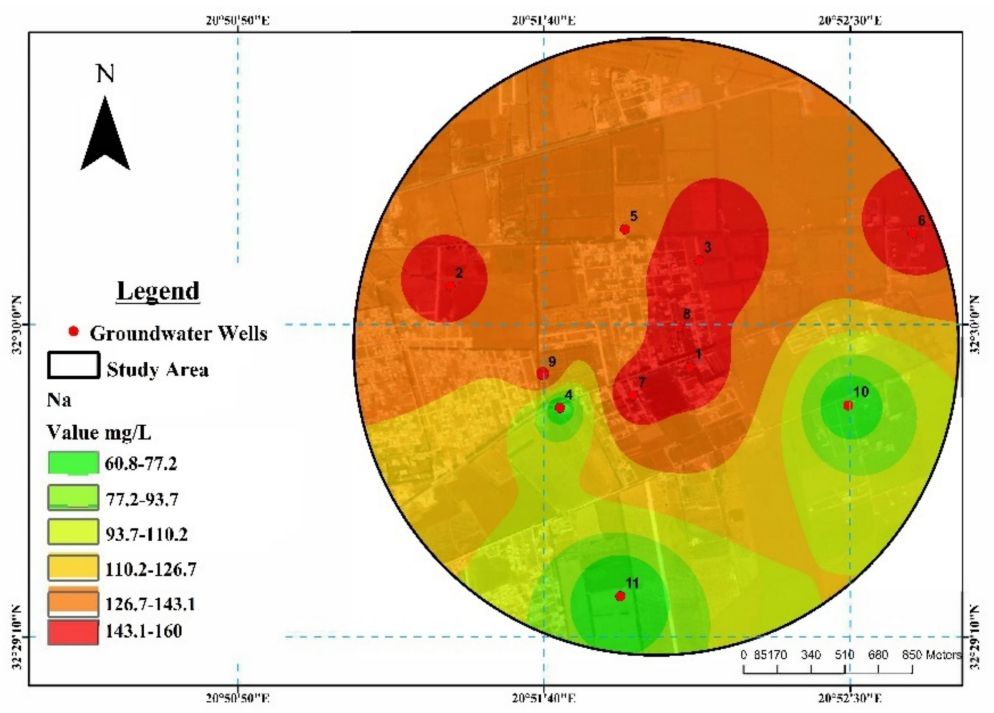

Figure 17. Spatial distribution map of Sodium.

\subsection{Copper}

The concentration of copper in the tested groundwater wells ranged from $0.0009 \mathrm{mg} / \mathrm{L}$ to $0.054 \mathrm{mg} / \mathrm{L}$, as presented in Table 18. The lowest value was recorded in the Abo Shuisha groundwater well $(0.0009 \pm 0.0007)$, whereas the highest concentration was found in the Salah Amtaual groundwater well $(0.054 \pm 0.01)$. The $\mathrm{Cu}$ concentration in the groundwater wells was less than the WHO's recommended limit for drinking water $(2 \mathrm{mg} / \mathrm{L})$. The presence of $\mathrm{Cu}$ metals could be due to corrosion from the plumbing system or from the rocks related to groundwater wells based on the geographical location of each well; corrosive water could also contribute to the increasing concentrations of $\mathrm{Cu}$ in water. The movement of copper relies on the characteristics of solid constitutes and the solution [64]. Santos et al. [65] conducted a study on groundwater in the city of Seville in Spain to determine the quality of water. They detected that the mean value of $\mathrm{Cu}$ was $0.021 \mathrm{mg} / \mathrm{L}$ and reported that the highest proportion of the metal was linked with dissolved organic materials and suspended matter. Significant differences were found amongst the $\mathrm{Cu}$ content of the studied groundwater wells $(p$-value $=0.00)$.

Table 18. Descriptive statistics and $p$-value of Copper (mg/L).

\begin{tabular}{cccccccccccc}
\hline Groundwater Wells & $\mathbf{1}$ & $\mathbf{2}$ & $\mathbf{3}$ & $\mathbf{4}$ & $\mathbf{5}$ & $\mathbf{6}$ & $\mathbf{7}$ & $\mathbf{8}$ & $\mathbf{9}$ & $\mathbf{1 0}$ & $\mathbf{1 1}$ \\
\hline Mean & 0.054 & 0.0035 & 0.0123 & 0.0021 & 0.0086 & 0.0083 & 0.0096 & 0.012 & 0.0096 & 0.001 & 0.0009 \\
Std Dev & 0.01 & 0.003 & 0.02 & 0.002 & 0.0017 & 0.014 & 0.0007 & 0.006 & 0.003 & 0.001 & 0.0007 \\
$p$-Value & 0.00 & & & & & & & & & & \\
WHO's guideline & 2 & & & & & & & & & & \\
\hline
\end{tabular}

The spatial distribution of copper in the measured groundwater wells is shown in Figure 18. In general, the obtained $\mathrm{Cu}$ proportion in the groundwater well was within the WHO's recommended limit for drinking water [24]. The distribution of Cu could be due to the locations of the groundwater wells near the city; these locations are affected by the mixed solid waste discharged from the town or due to leaky sewage. Emenike et al. [66] determined the quality of groundwater in southwestern Nigeria and revealed the absence of $\mathrm{Cu}$ in the studied groundwater wells. Yessuf et al. [66] investigated groundwater in the Visakhapatnam district of India and found that the concentration and distribution of $\mathrm{Cu}$ ranged from $0.0001 \mathrm{mg} / \mathrm{L}$ to $0.0286 \mathrm{mg} / \mathrm{L}$; the distribution of $\mathrm{Cu}$ differed from one place to another on the basis of the geographical location and environmental conditions of the well. 


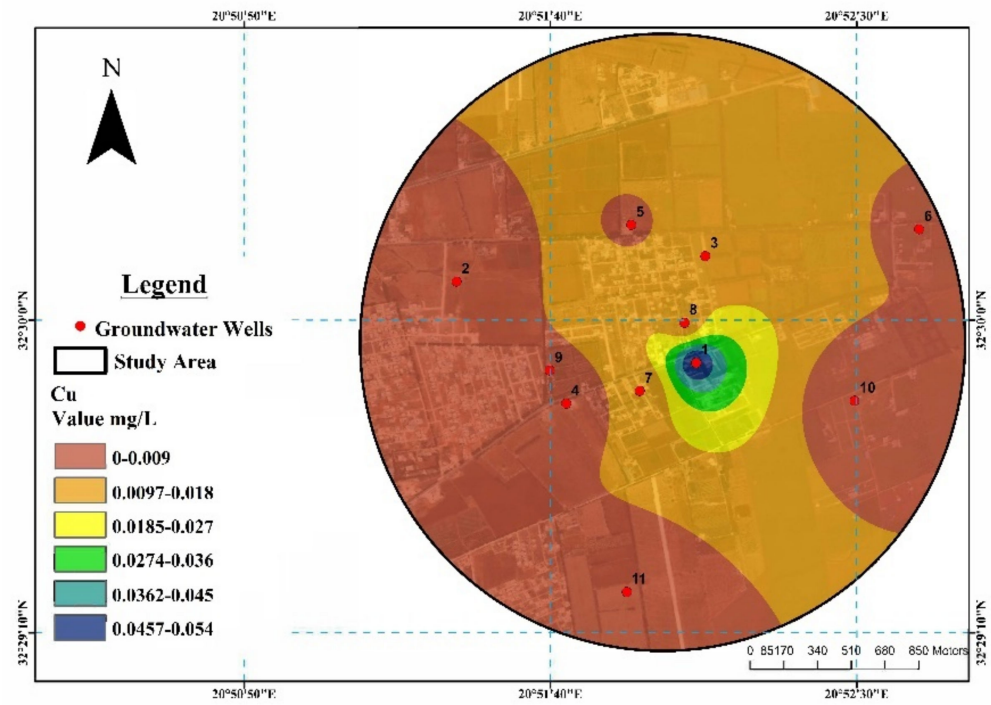

Figure 18. Spatial distribution map of Copper.

\subsection{Iron}

The concentration of iron in the groundwater wells was within $0.007-0.83 \mathrm{mg} / \mathrm{L}$, as shown in Table 19. The lowest value was found in the Idris Moftah groundwater well $(0.007 \pm 0.006)$, whereas the highest amount was detected in the Al Marthi groundwater well $(0.83 \pm 0.12)$. The Fe level in the groundwater wells was within the WHO's recommended limit for drinking water [24], except for the Al Marthi groundwater well where the iron content exceeded the allowable value of $0.3 \mathrm{mg} / \mathrm{L}$. The high amount of Fe in groundwater could be due to its natural presence because of the weathering of iron, minerals and rocks. In addition, industrial streaming, sewage and landfill leachate could contribute Fe to domestic groundwater. Rajappa et al. [67] investigated the heavy metal concentration in the groundwater in the Karnataka state of India and reported that the content of Fe ranged from $0.175 \mathrm{mg} / \mathrm{L}$ to $1.0 \mathrm{mg} / \mathrm{L}$ in the studied groundwater well. Kanoo and Jawed [68] identified the Fe concentration in the groundwater wells in Amingaon around the city of Guwahati in India and stated that the level of Fe varied between 0 and $11.03 \mathrm{mg} / \mathrm{L}$, which exceeded the allowable limit of $0.3 \mathrm{mg} / \mathrm{L}$ for drinking water. Significant differences were found amongst the iron content of the groundwater wells ( $p$-value $=0.00$ ).

Table 19. Descriptive statistics and $p$-value of Iron (mg/L).

\begin{tabular}{cccccccccccc}
\hline Groundwater Wells & $\mathbf{1}$ & $\mathbf{2}$ & $\mathbf{3}$ & $\mathbf{4}$ & $\mathbf{5}$ & $\mathbf{6}$ & $\mathbf{7}$ & $\mathbf{8}$ & $\mathbf{9}$ & $\mathbf{1 0}$ & $\mathbf{1 1}$ \\
\hline Mean & 0.22 & 0.26 & 0.83 & 0.07 & 0.05 & 0.04 & 0.02 & 0.04 & 0.07 & 0.06 & 0.007 \\
Std Dev & 0.1 & 0.12 & 0.12 & 0.07 & 0.03 & 0.04 & 0.17 & 0.03 & 0.08 & 0.06 & 0.006 \\
$p$-Value & 0.00 & & & & & & & & & & \\
WHO's guideline & 0.3 & & & & & & & & & & \\
\hline
\end{tabular}

Figure 19 illustrates the spatial distribution of iron in the groundwater wells in the study area. The highest allocation of Fe was found at three groundwater wells $(3,2,1)$, as shown in the figure below. The high distribution of Fe could be an indication of tillage activities, and it might be freed to water from natural deposits, industrial waste, refining of iron ore, and corrosion of Fe-containing metals. A similar study was conducted by Qiao et al. [69] in the Guanzhong region of China to evaluate the quality of groundwater and found that the concentration and distribution of Fe were lower than the limit for safe drinking water (i.e., $0.3 \mathrm{mg} / \mathrm{L}$ ). 


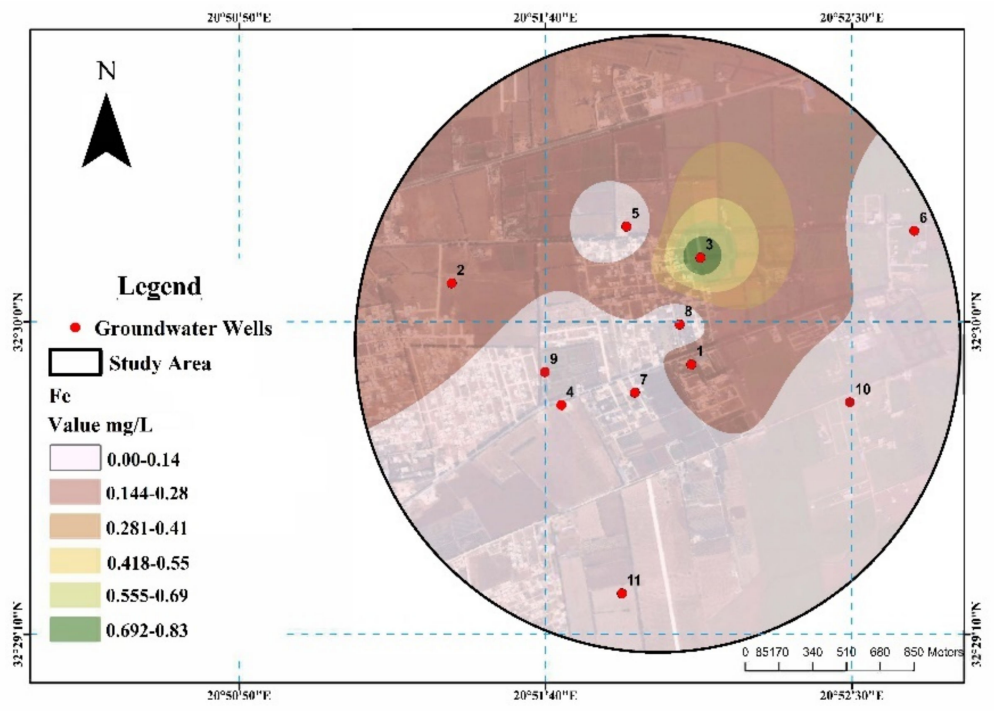

Figure 19. Spatial distribution map of Iron.

\subsection{Dissolved Oxygen}

The DO value in the groundwater wells was within $5.1-7 \mathrm{mg} / \mathrm{L}$, as illustrated in Table 20. The minimum value was determined in the Al Marthi groundwater well $(5.1 \pm 0.56)$, whereas the maximum level was reported in the Abo Shuisha groundwater well $(7 \pm 0.9)$. The richness of DO in the groundwater wells was higher than the WHOrecommended limit for drinking water [24]. The variation in the concentration of DO in the groundwater wells was due to the well's depth and groundwater temperatures. Cold water has a higher level of DO, whereas warm water has a lower level [70]. DO in underground water relies on the depth to the aquifers from which the water is coming from; shallow groundwater aquifers have a higher value than those in deeper areas [71]. Owamah [72] assisted a study on water quality and hand-dug wells in the Niger delta community in Nigeria and stated that the mean value of DO ranged from $8.00 \mathrm{mg} / \mathrm{L}$ to $12.00 \mathrm{mg} / \mathrm{L}$. No statistically significant variations were found in the DO amongst the groundwater wells $(p$-value $=0.09)$.

Table 20. Descriptive statistics and $p$-value of Dissolved Oxygen $(\mathrm{mg} / \mathrm{L})$.

\begin{tabular}{cccccccccccc}
\hline Groundwater Wells & $\mathbf{1}$ & $\mathbf{2}$ & $\mathbf{3}$ & $\mathbf{4}$ & $\mathbf{5}$ & $\mathbf{6}$ & $\mathbf{7}$ & $\mathbf{8}$ & $\mathbf{9}$ & $\mathbf{1 0}$ & $\mathbf{1 1}$ \\
\hline Mean & 6.7 & 6.9 & 5.1 & 5.2 & 5.9 & 5.2 & 6.4 & 5.4 & 6.4 & 5.2 & 7 \\
Std Dev & 1.2 & 1.3 & 0.56 & 0.46 & 0.82 & 0.53 & 0.81 & 1.25 & 1.41 & 0.4 & 0.9 \\
$p$-Value & 0.09 & & & & & & & & & & \\
WHO's guideline & 4 & & & & & & & & & & \\
\hline
\end{tabular}

The spatial distribution of DO in the groundwater wells is demonstrated in Figure 20. The high distribution of DO in several groundwater wells was due to organisms' activities and inversely related to water temperature, that is, cold water might result in more DO than warm water. Thus, DO considerably contributes to the quality of water concerning the stabilisation of numerous organic and inorganic contaminants in subterraneous water [73]. Distinctions in DO could occur seasonally or during the day in relevance to temperature and biological effectiveness (i.e., photosynthesis, respiration and organic breathing could lead to dissolution, thereby reducing the concentration of DO) [74]. 


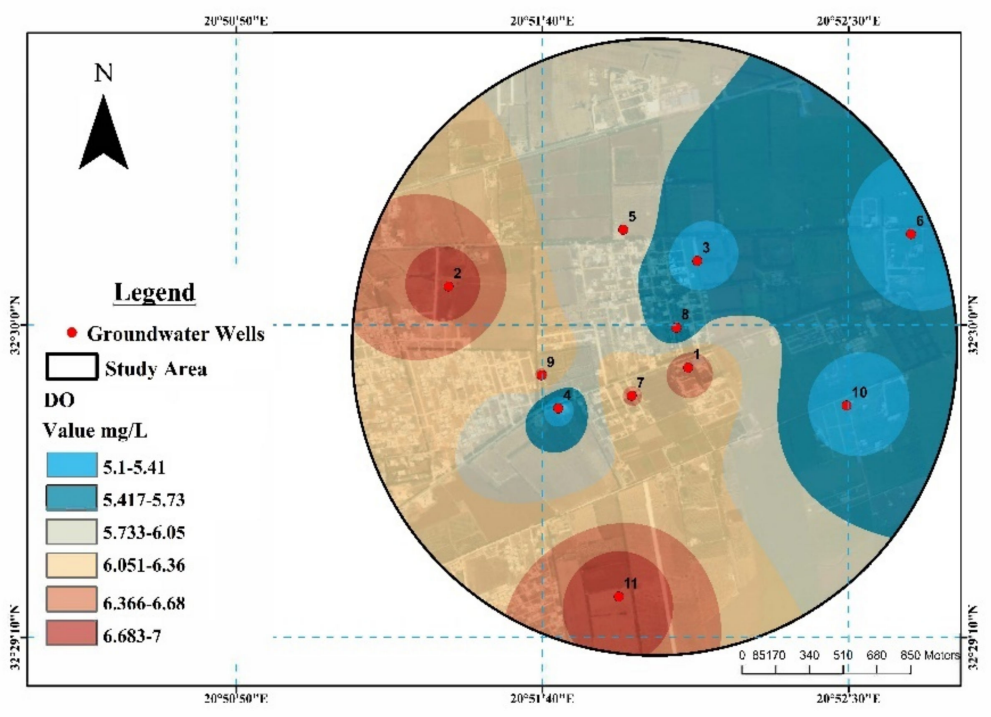

Figure 20. Spatial distribution map of Dissolved Oxygen.

\subsection{Biological Oxygen Demand}

The value of biochemical oxygen demand fluctuated from $1.03 \mathrm{mg} / \mathrm{L}$ to $6.25 \mathrm{mg} / \mathrm{L}$ in the studied groundwater wells, as shown in Table 21. The lowest level was recorded in the Agdora Al Abidi groundwater well $(1.03 \pm 0.58)$, whereas the highest amount was found in the Saad Mokhtar groundwater well $(6.25 \pm 0.13)$. In accordance with the WHOrecommended limit for drinking water [24], several groundwater wells were considered to have a high concentration of BOD5 (i.e., exceeding $3 \mathrm{mg} / \mathrm{L}$ ). The present findings indicate that the highest concentration of BOD5 in several groundwater wells could be due to the percolation of biodegradable organic matter and the leaching of inorganic matter into the aquifers. Contaminated water from sewage treatment stations carries natural substances that are decomposed by microorganisms, which utilise oxygen in the process. The amount of oxygen consumed by these organisms in breaking down wastes is known as biochemical oxygen demand [75]. The biochemical oxygen demand is also used as an indicator of the impact of groundwater from leachate. In cases where leachate is discharged directly into a watercourse, it will absorb oxygen from the water to complete its decomposition [76]. Significant differences were found amongst the BOD5 of the measured groundwater wells $(p$-value $=0.00)$.

Table 21. Descriptive statistics and $p$-value of Biological Oxygen Demand (mg/L).

\begin{tabular}{cccccccccccc}
\hline Groundwater Wells & $\mathbf{1}$ & $\mathbf{2}$ & $\mathbf{3}$ & $\mathbf{4}$ & $\mathbf{5}$ & $\mathbf{6}$ & $\mathbf{7}$ & $\mathbf{8}$ & $\mathbf{9}$ & $\mathbf{1 0}$ & $\mathbf{1 1}$ \\
\hline Mean & 1.97 & 3.86 & 6.16 & 6.25 & 1.16 & 3.95 & 1.03 & 1.32 & 2.06 & 3.2 & 2.24 \\
Std Dev & 0 & 0.11 & 0.14 & 0.13 & 0.07 & 0.32 & 0.58 & 0.2 & 0.44 & 0.26 & 0.34 \\
$p$-Value & 0.00 & & & & & & & & & & \\
WHO's guideline & 3 & & & & & & & & & & \\
\hline
\end{tabular}

Figure 21 displays the distribution of biochemical oxygen demand in the studied groundwater wells. The high distribution of $\mathrm{BOD}_{5}$ in some groundwater wells indicated the level of contamination. Increasing the concentration of turbidity with a lower value of dissolved oxygen could negatively affect the level of BOD which increasing the BOD level in the waterbody. The values and distribution obtained were similar to the outcomes reported by Agbalagba et al. [77], who confirmed that $\mathrm{BOD}_{5}$ varied between 1.34 and $9.55 \mathrm{mg} / \mathrm{L}$ and exceeded the WHO-recommended limit for drinking water [24]. This finding indicates the light pollution of groundwater due to solid organic waste. González et al. [78] reported that the increased value of $\mathrm{BOD}_{5}$ is an indication of the occurrence of biological activities 
in the water environment; however, the amount of organic matter decreases rapidly as a consequence of a substantial oxygen transfer rate due to high water turbulence.

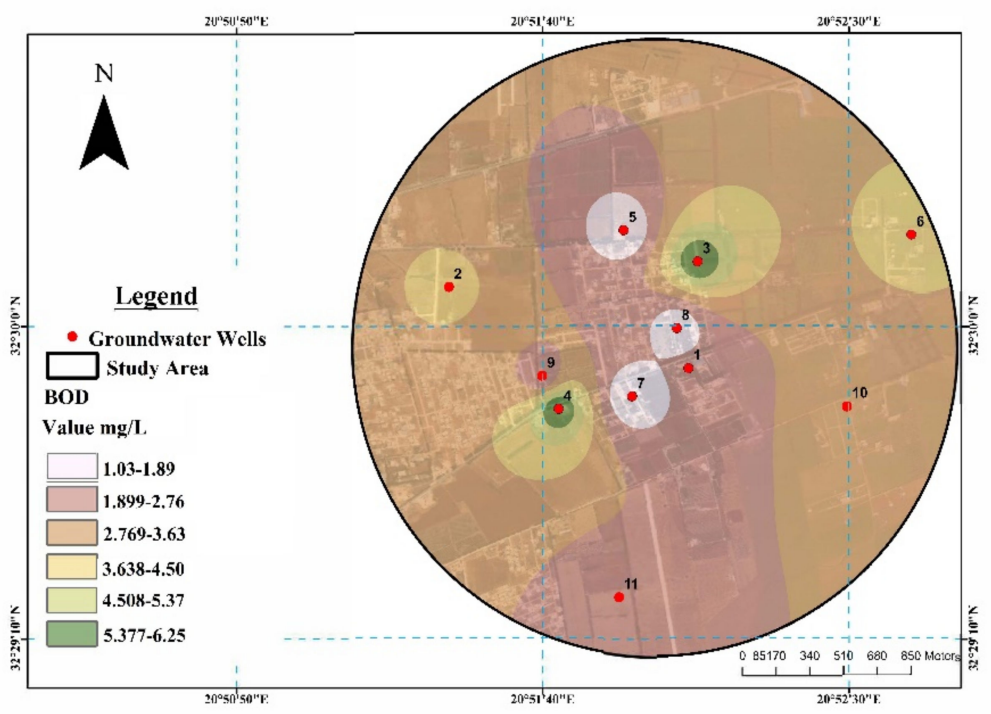

Figure 21. Spatial distribution map of Biological Oxygen Demand.

\subsection{Chemical Oxygen Demand}

The concentration of chemical oxygen demand (COD) in the measured groundwater wells ranged from $2.13 \mathrm{mg} / \mathrm{L}$ to $10.1 \mathrm{mg} / \mathrm{L}$, as shown in Table 22. The lowest value was reported in the Al Sahly groundwater well $(2.13 \pm 0.1)$, whereas the maximum level was found in the Ali Ibrahim groundwater well $(10.1 \pm 0.1$, which exceeded the limit for drinking water [i.e., $10 \mathrm{mg} / \mathrm{L}$ ]). The sources of COD in groundwater varied; however, soluble organic compounds were most likely to contribute to the increase in the value of COD and residual food waste from the residential area. COD is a measure of organic pollution from human and animal wastes and is used to assess the effects of humans and animals on water [79]. Similar findings were found by Zhang et al. [80], who determined the water quality in the city of Shanghai in China and proved that the value of COD ranged from $0.3 \mathrm{mg} / \mathrm{L}$ to $10 \mathrm{mg} / \mathrm{L}$. Significant variations were found in the COD of the groundwater wells $(p$-value $=0.00)$.

Table 22. Descriptive statistics and $p$-value of Chemical Oxygen Demand (mg/L).

\begin{tabular}{cccccccccccc}
\hline Groundwater Wells & $\mathbf{1}$ & $\mathbf{2}$ & $\mathbf{3}$ & $\mathbf{4}$ & $\mathbf{5}$ & $\mathbf{6}$ & $\mathbf{7}$ & $\mathbf{8}$ & $\mathbf{9}$ & $\mathbf{1 0}$ & $\mathbf{1 1}$ \\
\hline Mean & 4.41 & 8.25 & 9.26 & 9.34 & 2.13 & 10.1 & 2.25 & 3.7 & 3.07 & 5.62 & 3.61 \\
Std Dev & 0 & 0.2 & 0.7 & 0.3 & 0.1 & 0.1 & 0.1 & 0.1 & 0.4 & 0.3 & 0.2 \\
$p$-Value & 0.00 & & & & & & & & & & \\
WHO's guideline & 10 & & & & & & & & & & \\
\hline
\end{tabular}

Figure 22 shows the variation in the COD in the groundwater wells. The high COD distribution within the groundwater wells was due to wastewater and agricultural activities. Sajil Kumar et al. [81] conducted a study in the city of Ghaziabad in India and emphasised the distribution and concentration of COD in groundwater; they proved that the variation ranged from $4.50 \mathrm{ppm}$ to $20 \mathrm{ppm}$, indicating the presence of a different chemical combination reaching the areas of groundwater. The high concentrations of COD could be due to a large amount of oxidisable organic material in the water sample, thus decreasing the level of DO $[76,82]$. 


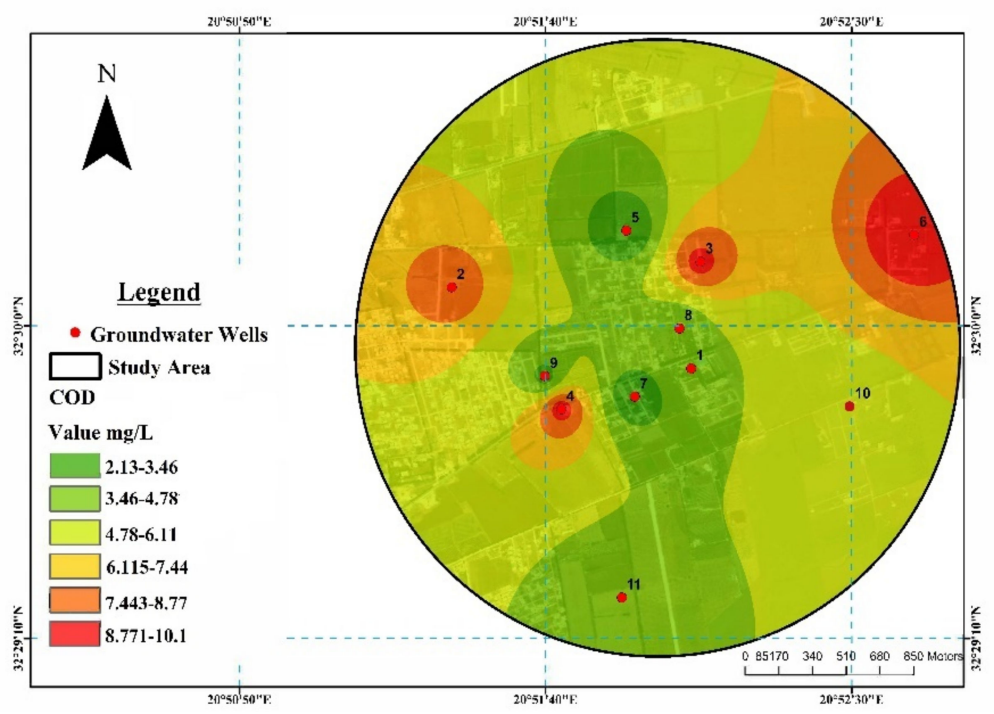

Figure 22. Spatial distribution map of Chemical Oxygen Demand.

\subsection{Total Suspended Solids}

The concentration of TSS ranged from $0.02 \mathrm{mg} / \mathrm{L}$ to $2.7 \mathrm{mg} / \mathrm{L}$, as demonstrated in Table 23. The lowest amount was detected in two groundwater wells, namely, Salam Edaab and Abo Shuisha $(0.02 \mathrm{mg} / \mathrm{L})$. The highest content was observed in the Ali Ibrahim groundwater well $(2.7 \pm 0.65)$. The low detection of TSS in the studied groundwater wells could be due to the nature of the soil composition of the water filtration process. No limit has been stipulated for TSS [83]. Hassan and Nawaz [84] assessed the groundwater quality in the Punjab Province of Pakistan and reported that TSS did not accumulate in the tested groundwater wells. Significant differences were found amongst the TSS values of the examined groundwater wells $(p$-value $=0.00)$.

Table 23. Descriptive statistics and $p$-value of Total Suspended Solids (mg/L).

\begin{tabular}{cccccccccccc}
\hline Groundwater Wells & $\mathbf{1}$ & $\mathbf{2}$ & $\mathbf{3}$ & $\mathbf{4}$ & $\mathbf{5}$ & $\mathbf{6}$ & $\mathbf{7}$ & $\mathbf{8}$ & $\mathbf{9}$ & $\mathbf{1 0}$ & $\mathbf{1 1}$ \\
\hline Mean & 0.41 & 0.02 & 0.65 & 0.21 & 0.25 & 2.7 & 0.21 & 0.77 & 0.19 & 0.11 & 0.02 \\
Std Dev & 0 & 0.02 & 0.14 & 0.11 & 0.13 & 0.65 & 0.21 & 0.13 & 0.12 & 0.11 & 0.03 \\
$p$-Value & 0.00 & & & & & & & & & & \\
WHO's guideline & NA & & & & & & & & & & \\
\hline
\end{tabular}

The spatial distribution of TSS in the groundwater wells is shown in Figure 23. The spatial pattern map of TSS indicated a clear water body and a lack of dry-weight suspended particles in the wells. The low concentration of TSS could be due to the lack of heavy rain even in the winter season in the region, which is geographically considered semidry to relatively dry; this finding did not support the movement of the suspended particles into the investigated groundwater wells. A similar pattern of the result was found by Kumari et al. [85] in their study in the city of Ghaziabad in India. The results were also consistent with those reported by Bisiriyu et al. [86], who examined the water quality of groundwater in Tudun Fulani, Niger State, Nigeria; they found that the concentration of TSS varied from $0.5 \mathrm{mg} / \mathrm{L}$ in November to $39.0 \mathrm{mg} / \mathrm{L}$ in January. This finding indicated that temporal differences in TSS represented a remarkable seasonal pattern during the rainy season. 


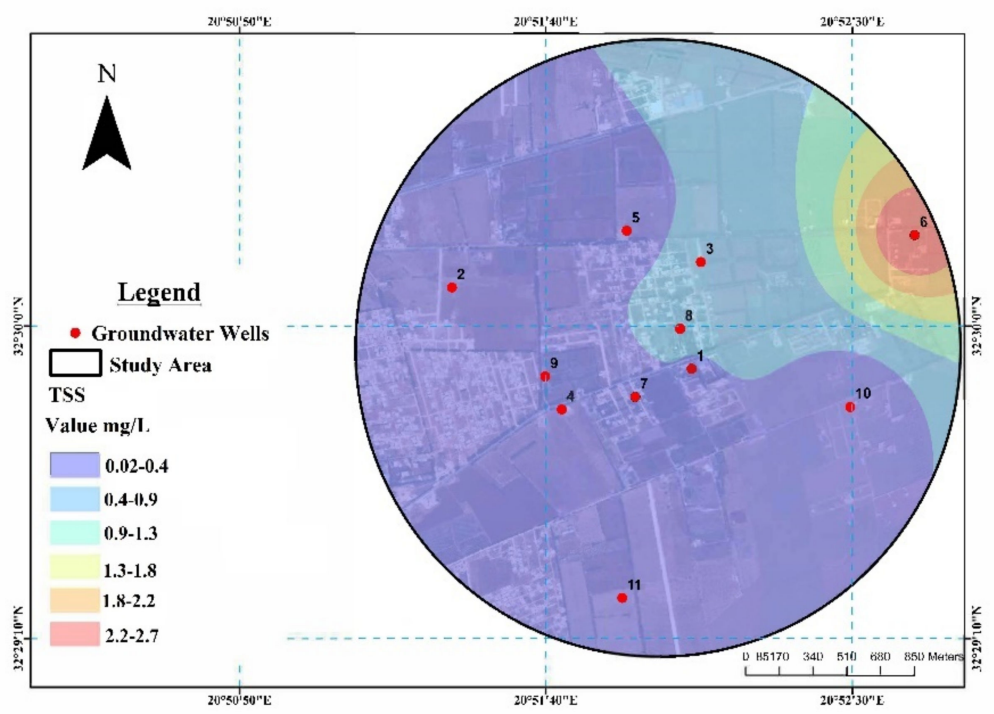

Figure 23. Spatial distribution map of Total Suspended Solids.

\subsection{E. Coli}

The prevalence of E. Coli in the measured groundwater wells was $0.00-8.00 \mathrm{CFU} / 100 \mathrm{~mL}$, as given in Table 24. The lowest positive result was observed in the Al Sahly groundwater well ( $3.00 \mathrm{CFU})$. The highest occurrence of E. coli was recorded in the Ali Ibrahim and Al Marthi groundwater wells (8.00 CFU). Five groundwater wells were affected by E. coli. The presence of $E$. coli in groundwater wells is a crucial public health concern. This microorganism affects groundwater wells because the sewage systems in the city are not working correctly to prevent the discharge of faecal contamination from infected humans or animals from reaching the groundwater wells. E. coli is the most commonly applied indicator of faecal contamination [87]. Najafi Saleh et al. [3] examined the groundwater quality in the Kwale Province of Kenya and reported that the prevalence of E. Coli in the groundwater wells ranged from intermediate to high risk. Significant differences were found amongst the amount of E. coli in the studied groundwater wells $(p<0.00)$.

Table 24. Descriptive statistics and $p$-value of E. Coli (CFU).

\begin{tabular}{cccccccccccc}
\hline Groundwater Wells & $\mathbf{1}$ & $\mathbf{2}$ & $\mathbf{3}$ & $\mathbf{4}$ & $\mathbf{5}$ & $\mathbf{6}$ & $\mathbf{7}$ & $\mathbf{8}$ & $\mathbf{9}$ & $\mathbf{1 0}$ & $\mathbf{1 1}$ \\
\hline Mean & 0.0 & 0.0 & 8.0 & 0.0 & 3.0 & 8.0 & 0.0 & 4.0 & 7.0 & 0.0 & 0.0 \\
Std Dev & 0 & 0 & 0 & 0 & 0 & 0 & 0 & 0 & 0 & 0 & 0 \\
$p$-Value & $*$ & & & & & & & & & & \\
WHO's guideline & 0 & & & & & & & & & & \\
\hline
\end{tabular}

* Zero Value of Std Dev between the analysis data of E. coli.

The spatial distribution of E. coli in the groundwater wells is depicted in Figure 24. The substantiation of E. Coli in the groundwater wells indicated that faecal contamination reached several wells due to the deterioration of the sewage network, causing the bacteria to reach the aquifers. The prevalence of $E$. Coli in some groundwater wells exceeded the WHO's recommended limit for drinking water [24]. It can be observed that there is a relationship of concentrations of some components in the groundwater wells, which was found to have a high concentration of BOD and decreased the value of DO and a high number of bacteria within the groundwater wells. The destroyed wastewater system network considerably contributed to the ejection of faecal content to the studied groundwater wells, resulting in a high concentration of $E$. coli in several wells. The presence of $E$. coli in groundwater indicated the increase in population density and faecal waste generation [88]. Daffi et al. [89] assessed the groundwater quality in the city of Jos in Nigeria and reported that E. coli prevalence 
was within 30-50 CFU; the high number could be attributed to the location of sewage contamination areas in relation to the groundwater wells.

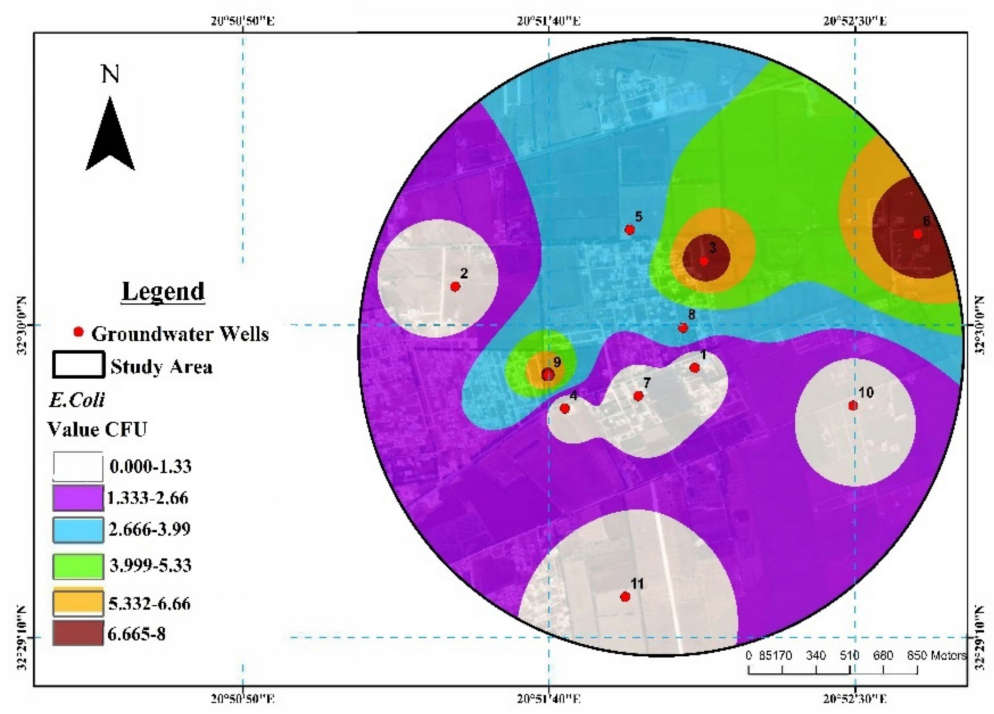

Figure 24. Spatial distribution map of E. coli.

\subsection{Total Coliforms}

The presence of TC in the groundwater wells was within 0.00-460 CFU/100 mL, as shown in Table 25. TC was detected in six groundwater wells in different numbers of propagations on the basis of their location in the study area and did not meet WHO's recommended safe limit for drinking water [24]. The highest MPN of TC (460 CFU) was found in the Ali Ibrahim groundwater well, which is adjacent to the city that is affected by sewage contamination caused by a poor sewage network. Therefore, neglect of the city's infrastructure and lack of regular maintenance in the sewage network considerably contributed to the pollution of the city and some groundwater wells in the study area. The current findings are consistent with those discussed by Mkandawire [90], who examined TC in the groundwater in the Blantyre district of Malawi; the mean values of TC were 181 CFU / $100 \mathrm{~mL}$ in the dry season and $717 \mathrm{CFU} / 100 \mathrm{~mL}$ in the wet season. Invik et al. [91] presented similar findings and proved that high contamination occurs during the rainy season due to the waterborne nature of bacteria. Significant differences were found amongst the TC of the examined groundwater wells $(p$-value $=0.00)$.

Table 25. Descriptive statistics and $p$-value of Total Coliforms (CFU).

\begin{tabular}{cccccccccccc}
\hline Groundwater Wells & $\mathbf{1}$ & $\mathbf{2}$ & $\mathbf{3}$ & $\mathbf{4}$ & $\mathbf{5}$ & $\mathbf{6}$ & $\mathbf{7}$ & $\mathbf{8}$ & $\mathbf{9}$ & $\mathbf{1 0}$ & $\mathbf{1 1}$ \\
\hline Mean & 0.0 & 0.0 & 240 & 0.0 & 39 & 460 & 0 & 39 & 210 & 7.0 & 0.0 \\
Std Dev & 0 & 0 & 0 & 0 & 0 & 0 & 0 & 0 & 0 & 0 & 0 \\
$p$-Value & $*$ & & & & & & & & & & \\
WHO's guideline & 0 & & & & & & & & & & \\
\hline
\end{tabular}

* Zero Value of Std Dev between the analysis data of Total Coliforms.

The enumeration and distribution of TC in the groundwater wells are demonstrated in Figure 25. The high distribution of TC was visible in three groundwater wells affected by the deteriorated sewage system network, which is located next to the sewage collection's lakelet. TC must not be found in the water used by humans in accordance with the drinking water quality standards by the WHO [24]. Stokdyk et al. [92] conducted a study on the groundwater quality of Minnesota, USA and confirmed the distribution and concentration of TC in 53 of 925 samples. Kausch et al. [93] evaluated the TC in the groundwater in Eastern Long Island in New York and found that $40 \%$ of the groundwater had a mean 
value of $1.3 \mathrm{CFU} / 100 \mathrm{~mL}$. In conclusion, TC in some of the groundwater wells exceeded the WHO's recommended limit for drinking water [24].

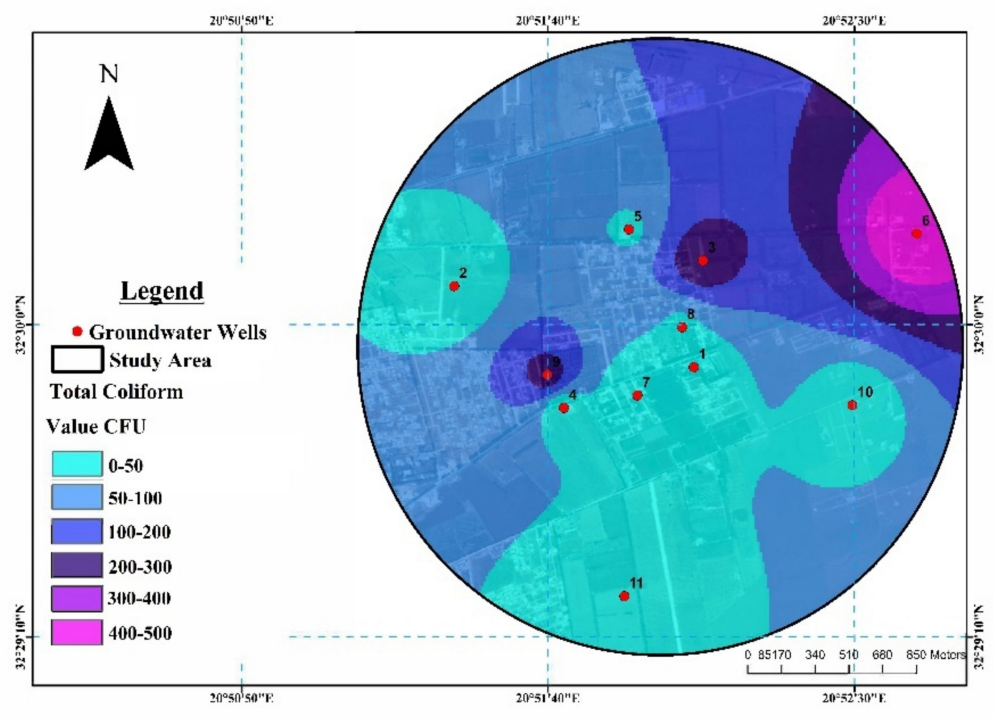

Figure 25. Spatial distribution map of Total Coliforms.

\section{Conclusions}

The city of Al-Marj in Libya has no available public water supply system due to the neglect of infrastructure. As a result, the population relies on groundwater for their needs. In this study, the eastern groundwater wells in the study area were investigated to estimate the suitability of its water for drinking, in comparison with the international standard recommended by the WHO [24]. EC was significantly high amongst the measured groundwater wells. Nine groundwater wells presented high concentrations of TDS and chloride. Calcium content was also remarkably high in the groundwater wells, except for the Abo Shuisha groundwater well. Moreover, most of the groundwater wells were contaminated by ammonia and ammoniacal nitrogen. High concentrations of DO were also reported in all the examined groundwater wells. The level of biological oxygen demand in five groundwater wells exceeded the safety limit, and only the Ali Ibrahim groundwater well presented a high concentration of COD. Several groundwater wells were notably polluted with E. Coli and TC. Furthermore, the groundwater was loaded with unacceptable quantities of some parameters; such quantities might have been obtained from a combination of sources, such as mineralisation, chemical weathering of rocks, industrial waste, sewage contamination, and intensive agricultural practices. The spatial distribution map of the physicochemical and biological parameters provided in the obtained data in the GIS environment can be used to determine a preferable groundwater location in the study area.

Author Contributions: Synthesis, J.R.J.H.; Characterisation, J.R.J.H., W.Z.Y., A.O.; Writing—Original Draft Preparation, J.R.J.H.; Writing—Review \& Editing, J.R.J.H.; Supervision, W.Z.Y., A.O. All authors have read and agreed to the published version of the manuscript.

Funding: This research was funded by the Universiti Kebangsaan Malaysia. This research was funded by a Research Grant from UKM-TNB Research (ST-2019-011).

Acknowledgments: The authors gratefully acknowledge financial support from the Faculty of Science and Technology, Universiti Kebangsaan Malaysia, Bangi 43600, Selangor, Malaysia. Special thanks to Marlia Mohd Hanafiah for her valuable knowledge at the early stage of this research. Not forgotten to thanks the High Ministry of Education in Libya for their financial support during this study.

Conflicts of Interest: The authors declare no conflict of interest. 


\section{References}

1. Hamzaoui-Azaza, F.; Ameur, M.; Bouhlila, R.; Gueddari, M. Geochemical characterization of groundwater in a Miocene Aquifer, Southeastern Tunisia. Environ. Eng. Geosci. 2012, 18, 159-174. [CrossRef]

2. Nickson, R.T.; McArthur, J.M.; Shrestha, B.; Kyaw-Myint, T.O.; Lowry, D. Arsenic and other drinking water quality issues, Muzaffargarh District, Pakistan. Appl. Geochem. 2005, 20, 55-68. [CrossRef]

3. Najafi Saleh, H.; Valipoor, S.; Zarei, A.; Yousefi, M.; Asghari, F.B.; Mohammadi, A.A.; Amiri, F.; Ghalehaskar, S.; Khaneghah, A.M. Assessment of groundwater quality around municipal solid waste landfill by using water quality index for groundwater resources and multivariate statistical technique: A case study of the landfill site, Qaem Shahr City, Iran. Environ. Geochem. Health 2020, 42, 1305-1319. [CrossRef] [PubMed]

4. Loh, Y.S.A.; Akurugu, B.A.; Manu, E.; Aliou, A.S. Assessment of groundwater quality and the main controls on its hydrochemistry in some Voltaian and basement aquifers, northern Ghana. Groundw. Sustain. Dev. 2020, 10, 100296. [CrossRef]

5. Wheida, E.; Verhoeven, R. An alternative solution of the water shortage problem in Libya. Water Resour. Manag. 2007, 21, 961-982. [CrossRef]

6. Nair, G.A.; Bohjuari, J.A.; Al-Mariami, M.A.; Attia, F.A.; El-Toumi, F.F. Groundwater quality of north-east Libya. J. Environ. Biol. 2006, 27, 695-700.

7. Jouda, J.H.R.; Hanafiah, M.M.; Yaakob, W.Z.W. Water resources management in Libya: Challenges and future prospects. Malaysian J. Sustain. Agric. 2017, 1, 2-5. [CrossRef]

8. Tuinhof, A.; Foster, S.; van Steenbergen, F.; Talbi, A.; Wishart, M. Appropriate groundwater management policy for Sub-Saharan Africa. Appropr. Groundw. Manag. Policy Sub. Saharan Africa 2011. [CrossRef]

9. Rashrash, S.M.; Ben Ghawar, B.M.; Hweesh, A.M. Evaluating groundwater pollution using hydrochemical data: Case study (Al Wahat Area East of Libya). J. Water Resour. Prot. 2015, 7, 369-377. [CrossRef]

10. Abd El-Aziz, S.H. Evaluation of groundwater quality for drinking and irrigation purposes in the north-western area of Libya (Aligeelat). Environ. Earth Sci. 2017, 76. [CrossRef]

11. Nnamani, E. Lack of Access to Potable Water Supply and Its Impact on the Nigerian Rural Communities. 2018. Available online: https:/ / www.researchgate.net/publication (accessed on 23 December 2020).

12. Jaouda, J.R.H.; Hanafiah, M.M.; Abdullah, S. Problems and current practices of solid waste management in the city of Al-marj, Libya. J. Clean WAS 2017, 1, 1-5. [CrossRef]

13. El-Barasi, Y.M.; Saaed, M.W.B.; El-Amrouni, A.O.; Mohamad, N.F. Check list of flora and vegetation on south El-Marj zone: South El-Jabal El-Akhadar-Libya. Ann. Fac. Eng. Hunedora 2011, 9, 141.

14. Bartram, J.; Ballance, R. Water Quality Monitoring-A Practical Guide to the Design and Implementation of Freshwater; Qual. Stud. Monit. Program; CRC Press: Boca Raton, FL, USA, 1996; pp. 1-348. ISBN 0-419-21730-4. Available online: https://apps.who.int/ iris/handle/10665/41851 (accessed on 25 December 2020).

15. Baird, R.B.; Eaton, A.D.; Rice, E.W.; Bridgewater, I. American Public Health Association (APHA). Standard Methods for the Examination of Water and Wastewater, 23th ed.; American Public Health Association/American Water Works Association/Water Environment Federation: Washington, DC, USA, 2017.

16. Canadian Council of Ministers of the Environment (CCME). Introduction. Updated. In Canadian Environmental Quality Guidelines 1999; Canadian Council of Ministers of the Environment (CCME): Winnipeg, MB, Canada, 2001; Available online: https:/ /www. ccme.ca/en/resources/canadian_environmental_quality_guidelines / (accessed on 15 October 2020).

17. Sayato, Y. WHO guidelines for drinking-water quality. Eisei Kagaku 1989, 35, 307-312. [CrossRef]

18. HACH. Company. DR/890 Colorimeter Procedures Manual; HACH: Loveland, CO, USA, 2013; p. 616.

19. Mostafa, H.; Al-wasify, R.S.; Sayed, A.M.; Bakry, M. Microbiological and Physicochemical Evaluation of Groundwater in Egypt. Int. J. Environ. Sustain. 2013, 2, 1-10. [CrossRef]

20. Parmar, P.J. The studies on underground water quality of some villages of chalisgaon blocks along the north side of Girna Canal (Right) of Jalgaon. Oriental J. Chem. 2012, 28, 927-931. [CrossRef]

21. Nhua, H.E. Coseismic groundwater temperature response associated with the Wenchuan earthquake. Pageoph 2019. [CrossRef]

22. Chacha, N.; Njau, K.N.; Lugomela, G.V.; Muzuka, A.N.N. Hydrogeochemical characteristics and spatial distribution of groundwater quality in Arusha well fields, Northern Tanzania. Appl. Water Sci. 2018, 8, 1-23. [CrossRef]

23. Suk-ueng, K.; Chantima, K.; Prasertsin, T. Spatial distribution of soil quality using geoinformatics in agricultural areas in Nang Lae Sub-district, Mueang District, Chiang Rai Province. Intern. J. Agricult. Technol. 2019, 15, 779-790.

24. World Health Organization (WHO). Guidelines for Drinking Water Quality [Electronic Resource]: Incorporating First Addendum. Volume 1, Recommenda-tions, 3rd ed.; WHO: Geneva, Switzerland, 2006; Available online: https://www.who.int/water_sanitation_ health/dwq/gdwq0506.pdf (accessed on 5 October 2020).

25. Brhane, G.K. Characterization of hydro chemistry and groundwater quality evaluation for drinking purpose in Adigrat area, Tigray, northern. TITLE Water Sci. 2018, 2017. [CrossRef]

26. Nas, B.; Berktay, A. Groundwater quality mapping in urban groundwater using GIS. Environ. Monit. Assess. 2008, 160, 215-227. [CrossRef]

27. Akinbile, C.O.; Yusoff, M.S. Environmental impact of leachate pollution on groundwater supplies in Akure, Nigeria. IJESD 2011. [CrossRef] 
28. Alfaifi, H.J.; Kahal, A.Y.; Abdelrahman, K.; Zaidi, F.K.; Albassam, A.; Lashin, A. Assessment of groundwater quality in Southern Saudi Arabia: Case study of Najran area. Arab. J. Geosci. 2020, 13, 1-15. [CrossRef]

29. Dzwairo, B.; Hoko, Z.; Love, D.; Guzha, E. Assessment of the impacts of pit latrines on groundwater quality in rural areas: A case study from Marondera district, Zimbabwe. Phys. Chem. Earth 2006, 31, 779-788. [CrossRef]

30. Qaseem, N.M.A.; Al-Barwary, M.R.A. Evaluation of physical and chemical quality of well water in Zakho District, Kurdistan region, Iraq Evaluation of physical and chemical quality of well water in Zakho District, Kurdistan region. Iraq. IOP Conf. 2018. [CrossRef]

31. Mahmood, K.; Kamal, A.A.; Hama, A.R. Study and evaluation of stored drinking water characteristics using three types of roof water tanks in Kirkuk Governorate, Iraq. WJES 2018, 11-16. [CrossRef]

32. Gopinath, G.; Laluraj, C.M. Assessment on seasonal variation of groundwater. Environ. Monit. Assess. 2006, 45-57. [CrossRef]

33. El-salam, M.M.A.; Abu-zuid, G.I. Impact of landfill leachate on the groundwater quality: A case study in Egypt. J. Adv. Res. 2014. [CrossRef]

34. Wei, Y.; Wu, S.; Chou, C.; Che, C.; Tsai, S.; H. Lien, H. Influence of nanoscale zero-valent iron on geochemical properties of groundwater and vinyl chloride degradation: A field case study. Water Res. 2009, 1-10. [CrossRef]

35. Shah, M.; Sircar, A.; Shaikh, N.; Thakar, V.; Sharma, D.; Vaidya, D. Author's accepted manuscript. Groundw. Sustain. Dev. 2018. [CrossRef]

36. Geological, J.; Of, S. Factor and cluster analysis of water quality data of the Groundwater wells of Kushtia, Bangladesh: Implication for arsenic enrichment and mobilization. JGSI 2013, 81, 377-384.

37. Lorite-Herrera, M.; Jiménez-Espinosa, R. Impact of agricultural activity and geologic controls on groundwater quality of the alluvial aquifer of the Gualquivir River (province of Jaen Spain): A case study. Environ. Geol. 2008, 1391-1402. [CrossRef]

38. Biglari, H.; Chavoshani, A.; Javan, N.; Hossein Mahvi, A. Geochemical study of groundwater conditions with special emphasis on fluoride concentration, Iran. Desalin. Water Treat. 2016, 57, 22392-22399. [CrossRef]

39. Boyd, C.E. Water Quality, An Introduction; Kluwer Academic Publishers: Boston, MA, USA, 2000; 330p.

40. James, M. Spatial analysis of Groundwater sources in the duport road (shara and cow field) and soul clinic diamond creek communities, Paynesville City, Republic of Liberia. IJSRST 2017, 3, 1-12.

41. Talat, R.A.; Al-Assaf, A.Y.; Al-Saffawi, A.Y. Valuation of water quality for drinking and domestic purposes using WQI: A case study for groundwater of Al-Gameaa and Al-Zeraee qaurters in Mosul city/Iraq. JPCS 2019. [CrossRef]

42. Deshpande, S.M.; Aher, K.R.; Gaikwad, G.D. Assessment of groundwater quality and its suitability for drinking uses in warora tehsil, district chandrapur, India introduction. Int. J. Recent Trends Sci. Technol. 2012, 4, 120-124.

43. Liaghat, S.M.S.K.E.A.M. Groundwater quality assessment using the Water Quality Index and GIS in Saveh-Nobaran aquifer, Iran. Science 2013. [CrossRef]

44. Tikle, S.; Saboori, M.J.; Sankpal, R. Spatial distribution of ground water quality in some selected parts of pune city, Maharashtra, India using GIS. Curr. World Environ. 2012, 7, 281-286. [CrossRef]

45. Belkhiri, L.; Narany, T.S. Using multivariate statistical analysis, geostatistical techniques and structural equation modeling to identify spatial variability of Groundwater quality. Water Resour. Manag. 2015, 29, 2073-2089. [CrossRef]

46. Kringel, R.; Rechenburg, A.; Kuitcha, D.; Fouépé, A.; Bellenberg, S.; Kengne, I.M.; Fomo, M.A. Mass balance of nitrogen and potassium in urban groundwater in Central Africa, Yaounde/Cameroon. Sci. Total Environ. 2016, 547, 382-395. [CrossRef]

47. Shomar, B.; Fakher, S.A.; Yahya, A. Assessment of Groundwater quality in the Gaza strip, Palestine using GIS mapping. J. Water Resour. Prot. 2010, 2, 93-104. [CrossRef]

48. Chenini, I.; Farhat, B.; Mammou, A.B. Identification of major sources controlling groundwater chemistry from a multilayered aquifer system. Chem. Speciat. Bioavailab. 2010, 22, 183-189. [CrossRef]

49. Kouras, A.; Katsoyiannis, I.; Voutsa, D. Distribution of arsenic in groundwater in the area of Chalkidiki, Northern Greece. J. Hazard. Mater. 2007, 147, 890-899. [CrossRef]

50. Kazi, T.G.; Arain, M.B.; Jamali, M.K.; Jalbani, N.; Afridi, H.I.; Sarfraz, R.A.; Baig, J.A.; Shahet, A.Q. Assessment of water quality of polluted lake using multivariate statistical techniques: A case study. Ecotoxicol. Environ. Saf. 2009, 72, 301-309. [CrossRef] [PubMed]

51. Fu, Q.; Zheng, B.; Zhao, X.; Wang, L.; Liu, C. Ammonia pollution characteristics of centralized drinking water sources in China. J. Environ. Sci. 2012, 24, 1739-1743. [CrossRef]

52. Harms-ringdahl, P. Identifying Possible Sources of Ammonium Ions and Arsenic in Groundwater in the Nam Du Area, Vietnam. Master's Thesis, Hanoi Univ. of Mining and Geology Vietnam, Hanoi, Vietnam, 2007; p. 82.

53. Jafari, M.T.; Khayamian, T. Direct determination of ammoniacal nitrogen in water samples using corona discharge ion mobility spectrometry. Talanta 2008, 76, 1189-1193. [CrossRef] [PubMed]

54. Shakya, B.M.; Nakamura, T.; Kamei, T.; Das Shrestha, S.; Nishida, K. Seasonal groundwater quality status and nitrogen contamination in the shallow aquifer system of the Kathmandu Valley, Nepal. Water 2019, 11, 2184. [CrossRef]

55. Wu, Z.; Ye, Q. Water pollution loads and shifting within China's inter-province trade. J. Clean. Prod. 2020, 259, 120879. [CrossRef]

56. Wakida, F.T.; Lerner, D.N. Non-agricultural sources of groundwater nitrate: A review and case study. Water Res. 2005, 39, 3-16. [CrossRef]

57. Keeney, D.; Olson, R.A. Sources of nitrate to ground water. Crit. Rev. Environ. Control 1986, 16. [CrossRef] 
58. Wagh, V.M.; Panaskar, D.B.; Mukate, S.V.; Aamalawar, M.L.; Sahu, L.U. Nitrate associated health risks from groundwater of Kadava river Basin Nashik, Maharashtra, India. Hum. Ecol. Risk Assess. 2020, 26, 654-672. [CrossRef]

59. El Hamidi, M.J.; Larabi, A.; Faouzi, M.; Souissi, M. Spatial distribution of regionalized variables on reservoirs and groundwater resources based on geostatistical analysis using GIS: Case of Rmel-Oulad Ogbane aquifers (Larache, NW Morocco). Arab. J. Geosci. 2018, 11. [CrossRef]

60. Odoma, L.; Ocheri, M.I. Spatial Variability of Nitrate Levels in Groundwater of Lokoja Town, Kogi State, Nigeria. Curr. J. Appl. Sci. Technol. 2020, 39, 7-11. [CrossRef]

61. Siemens, M.; Dynes, J.J.; Chang, W. Sodium adsorption by reusable zeolite adsorbents: Integrated adsorption cycles for salinised groundwater treatment. Environ. Technol. 2020, 1-41. [CrossRef] [PubMed]

62. Rezaei, H.; Ryan, B.; Stoianov, I. Pipe failure analysis and impact of dynamic hydraulic conditions in water supply networks. Procedia Eng. 2015, 119, 253-262. [CrossRef]

63. Adimalla, N.; Taloor, A.K. Hydrogeochemical investigation of groundwater quality in the hard rock terrain of South India using Geographic Information System (GIS) and groundwater quality index (GWQI) techniques. Groundw. Sustain. Dev. 2019, 100288. [CrossRef]

64. Małecki, J.; Kadzikiewicz-Schoeneich, M.; Szostakiewicz-Hołownia, M. Concentration and mobility of copper and zinc in the hypergenic zone of a highly urbanized area. Environ. Earth Sci. 2016, 75, 1-13. [CrossRef]

65. Santos, A.; Alonso, E.; Callejón, M.; Jiménez, J.C. Distribution of $\mathrm{Zn}, \mathrm{Cd}, \mathrm{Pb}$ and Cu metals in groundwater of the Guadiamar River Basin. Water. Air. Soil Pollut. 2002, 134, 275-286. [CrossRef]

66. Yessuf, M.H. Geospatial study on characterization of Groundwater in Bheemunipatnam Municipality, Visakhapatnam District, Andhra Pradesh, India. IJERT 2018, 7, 175-184.

67. Rajappa, B.; Manjappa, S.; Puttaiah, E. Monitoring of Heavy Metal Concentration in Groundwater of Hakinaka Taluk, India. Contemp. Eng. Sci. 2010, 3, 183-190.

68. Kanoo, B.; Jawed, M. Assessing iron (II) and fluoride removals by indigenously fabricated household water filter of north Guwahati. Lect. Notes Civ. Eng. 2020, 57, 91-103. [CrossRef]

69. Qiao, Y.; Zhu, X.; Jia, M.; Shao, X.; Niu, X.; Liu, J. Distributions of arsenic and other heavy metals, and health risk assessments for groundwater in the Guanzhong Plain region of China. Environ. Res. 2020, 181, 108957. [CrossRef] [PubMed]

70. Zan, J.; Dong, Y.; Zhang, W.; Xu, W.; Li, J.; Gao, B.; Hu, F.; Wang, Q. Distribution characteristics of dissolved oxygen and stable isotope compositions of shallow groundwater in the vicinity of an inland nuclear power plant, HK, China. E3S Web Conf. 2019, 98, 4. [CrossRef]

71. Yan, M.; Herrmann, B.; Kampe, R.; Lehmann, K.; Totsche, U.; Küsel, K. Environmental selection shapes the formation of near-surface groundwater microbiomes. Water Res. 2020, 170, 115341. [CrossRef] [PubMed]

72. Owamah, H.I. A comprehensive assessment of groundwater quality for drinking purpose in a Nigerian rural Niger delta community. Groundw. Sustain. Dev. 2020, 10, 100286. [CrossRef]

73. Abiriga, L.; Vestgarden, S.; Klempe, H. Groundwater contamination from a municipal landfill: Effect of age, landfill closure, and season on groundwater chemistry. Sci. Total Environ. 2020, 737, 140307. [CrossRef]

74. Cox, B.A. A review of dissolved oxygen modelling techniques for lowland rivers. Sci. Total Environ. 2003, 314-316, 303-334. [CrossRef]

75. Hanipha, A.; Hussain, Z. Study of Groundwater quality at Dindigul town, Tamilnadu, India. Int. Res. J. Environ. Sci. 2019, $2,68-73$.

76. Koda, E.; Miszkowska, A.; Sieczka, A. Levels of organic pollution indicators in groundwater at the old landfill and waste management site. Appl. Sci. 2017, 7, 638. [CrossRef]

77. Agbalagba, O.; Agbalagba, H.; Ononugbo, C.P.; Alao, A.A. Investigation into the physico-chemical properties and hydrochemical processes of groundwater from commercial boreholes In Yenagoa, Bayelsa State, Nigeria. Afr. J. Environ. Sci. Technol. 2011, $5,473-481$.

78. González, S.O.; Almeida, C.A.; Calderón, M.; Mallea, M.A.; González, P. Assessment of the water self-purification capacity on a river affected by organic pollution: Application of chemometrics in spatial and temporal variations. Environ. Sci. Pollut. Res. 2014, 21, 10583-10593. [CrossRef]

79. Negi, P.; Mor, S.; Ravindra, K. Impact of landfill leachate on the groundwater quality in three cities of North India and health risk assessment. Environ. Dev. Sustain. 2020, 22, 1455-1474. [CrossRef]

80. Zhang, Z.; Yuan, Y.; Fang, Y.; Liang, L.; Ding, H.; Jin, L. Preparation of photocatalytic nano-ZnO/TiO2 film and application for determination of chemical oxygen demand. Talanta 2007, 73, 523-528. [CrossRef] [PubMed]

81. Sajil Kumar, P.J.; Elango, L.; James, E.J. Assessment of hydrochemistry and groundwater quality in the coastal area of South Chennai, India. Arab. J. Geosci. 2014, 7, 2641-2653. [CrossRef]

82. Ngang, B.U.; Agbazue, V.E. A seasonal assessment of Groundwater pollution due to biochemical oxygen demand, chemical oxygen demand and elevated temperatures in Enugu Northern Senatorial District, South East Nigeria. IOSR-JAC 2016, 9, 66-73. [CrossRef]

83. Sojobi, A.O. Evaluation of groundwater quality in a rural community in North Central of Nigeria. Environ. Monit. Assess. 2016, 188, 1-17. [CrossRef]

84. Hassan, A.; Nawaz, M. Microbiological and physicochemical assessments of groundwater quality at Punjab, Pakistan. Afr. J. Microbiol. Res. 2014, 8, 2672-2681. [CrossRef] 
85. Kumari, S.; Singh, A.K. Assessment and spatial distribution of groundwater quality in industrial areas of Ghaziabad, India. Environ. Monit. Assess 2013, 2014. [CrossRef]

86. Bisiriyu, M.T.; Ganiyu, M.A.; Audu, L.I.; Abdullahi, A.S.; Animashaun, I.M. An Assessment of Groundwater Quality in Tudun Fulani, Niger State, Nigeria. SLUJST 2020, 1, 7-16.

87. Figueras, M.J.; Borrego, J.J. New perspectives in monitoring drinking water microbial quality. Int. J. Environ. Res. Public Health 2010, 7, 4179-4202. [CrossRef]

88. Yang, M.; Li, Y.; Wang, L.; Wang, L.; Niu, L. Hydrodynamic conditions influence bacterial growth and phenol biodegradation of strains with different morphology and motility. Water. Air. Soil Pollut. 2018, 229. [CrossRef]

89. Daffi, R.E.; Alfa, M.I.; Ibrahim, E.S. Gis-based analysis of water quality parameters of Groundwater with proximity to onsite wastes pits in vom community of Jos South, Nigeria. J. Eng. Res. Rep. 2020, 10, 6-18. [CrossRef]

90. Mkandawire, T. Quality of groundwater from shallow wells of selected villages in Blantyre District, Malawi. Phys. Chem. Earth 2008, 33, 807-811. [CrossRef]

91. Invik, J.; Barkema, H.W.; Massolo, A.; Neumann, N.F.; Checkley, S. Total coliform and Escherichia coli contamination in rural well water: Analysis for passive surveillance. J. Water Health 2017, 15, 729-740. [CrossRef] [PubMed]

92. Stokdyk, J.P.; Firnstahla, A.D.; Walshb, J.F.; Spencerc, S.K.; de Lambertb, J.R.; Anderson, A.C.; Rezania, L.-I.W.; Kieke, A.B., Jr.; Borchardt, M.A. Viral, bacterial, and protozoan pathogens and fecal markers in wells supplying groundwater to public water systems in Minnesota, MN, USA. Water Res. 2020, 178, 115814. [CrossRef]

93. Kausch, M.E.; Fisher, S.C.; Fisher, I.J.; Phillips, P.J.; Mullan, G.D.O. Bacterial quality of groundwater downgradient of onsite wastewater disposal systems and the in fluence on eastern Long Island's embayments. Mar. Pollut. Bull. 2019, 2018, 110598. [CrossRef] 